\title{
1 Origin and evolution of the Haustoriidae (Amphipoda): A eulogy for
}

\section{2 the Haustoriidira}

4 Running Title: Origin of Haustoriidae

6 Zachary B. Hancock*1,2, Hiroshi Ogawa ${ }^{3}$, Jessica E. Light ${ }^{2,4}$, Mary K. Wicksten ${ }^{1,2}$

$8 \quad{ }^{1}$ Department of Biology at Texas A\&M University

$9 \quad{ }^{2}$ Ecology and Evolutionary Biology Interdisciplinary Program at Texas A\&M University

$10{ }^{3}$ Association for Protection of Marine Communities, 69 Jodoji-shimobanbacho, Sakyo, Kyoto

11 606-8413, Japan E-mail: haustorioides@gmail.com

$12{ }^{4}$ Department of Ecology and Conservation Biology at Texas A\&M University

13 *Corresponding author: zhancock@bio.tamu.edu 


\section{ABSTRACT}

17 Haustoriid amphipods, despite their ubiquity in coastal sand or mud, have received little recent

18 attention and their systematics and phylogenetics are largely unresolved. Some efforts have been made at classifying the family within the broader Amphipoda, but there is persistent

20 incongruence in its placement among different authors and techniques. Furthermore, there exists

21 no phylogenetic hypothesis of intrafamilial relationships despite the potential for rich

22 biogeographic information to be gained given the specific habitat requirements of haustoriids and

23 their limited dispersal abilities. In this work, we evaluate the competing hypotheses on the

24 phylogenetic position of the Haustoriidae within Amphipoda by examining new and previously

25 published sequences of nearly 100 species across 38 families. We find strong support for the

26 Haustoriidae as basal gammarids, and that other families placed within the parvorder

27 "Haustoriidira" are spread across Amphipoda. The radiation began during the Eocene and may

28 have been driven in North America by the rapid filling of a coastal niche opened by the

29 Chesapeake Bay impact crater. Unlike previous work, we find that the Pacific-endemic genus

30 Eohaustorius is the most basal haustoriid, and that it separated from the rest of the family $\sim 31$

31 Mya. Finally, based on ancestral reconstructions, we provide taxonomic recommendations for

32 relationships within Haustoriidae, including the elevation of a new genus, Cryptohaustorius. We

33 conclude by recommending that the "Haustoriidira" be abandoned.

35 KEYWORDS: Biogeography, divergence-time, homoplasy, phylogenetics, sand-burrowing, 


\section{INTRODUCTION}

38

Amphipoda is an incredibly diverse order of crustaceans with nearly 10,000 described species (Barnard, 1957; Lowry \& Myers, 2017). One such family of amphipods with uncertain affinity, the Haustoriidae, were deemed by J. Laurens Barnard as "perhaps the most interesting group of amphipods" (Barnard, 1969) likely because they are highly morphologically specialized to a fossorial lifestyle. Haustoriids are found on both open and protected beaches around the world but are hypothesized to have originated in the western North Atlantic (Bousfield, 1970). These amphipods have broad, fusiform bodies, lack eye pigmentation, and sport a dizzying array of spines and setae that give them the appearance of a fuzzy, opaque bean (Fig. 1e). They have lost article 4 on their mandibular palp (article 3 is strongly geniculate in compensation) and they are characterized by the absence of dactyls on pereopods $3-7$. On gnathopods $1-2$, the dactyls have been highly reduced; on gnathopod 1 they are a thin, curved nail, whereas they compose a minute chela on gnathopod 2. Pereopods 3-4 are perhaps the most curious: article 6 forms an expanded cup-like structure that is lined by stout spines for digging through the sediment (except in Eohaustorius spp.; pereopod 4 is a miniature version of pereopod 5). The last three legs are broadly expanded with each article as wide as they are long, and densely lined with comb setae. The posterior of haustoriids are as bushy as the front, and they have evolved powerful uropods with strong apical spines that aid in propelling them through the sand.

Lowry \& Myers (2013) erected a suborder of Amphipoda, Senticaudata, on the basis of the supposedly synapomorphic robust apical spines on uropods 1 and 2 . This grouping includes many diverse and geographically widespread groups, such as the gammarids, talitrids, corophiids, and others. However, Lowry \& Myers (2013) argue that the phoxocephalids and 
60 haustoriids have acquired this trait convergently and are excluded from this suborder. Instead,

61 Lowry \& Myers (2017) place the haustoriids in the suborder Amphilochidea, allying them with

62 the pelagic lysianassids, the synopiids, and other fossorial amphipods included within the

63 parvorder Haustoriidira (see Taxonomy in Methods). Verheye et al. (2016) has called into

64 question the usefulness of the robust spines on the uropods for higher level classification, finding

65 that it appears to evolve convergently across many families.

The modern taxonomy of the Haustoriidae (as with many amphipod families) was shaped

67 by the morphological work of E.L. Bousfield and J. Laurens Barnard. Bousfield (1965) redefined

68 the family from Stebbing's (1906) original description, erecting two subfamilies: the

69 Haustoriinae (or the "true" haustoriids) and the Pontoporiinae (previously their own family, the

70 Pontoporiidae). In addition to the two haustoriid genera already recognized (Haustorius and

71 Lepidactylus), Bousfield (1965) described five new genera of haustoriids and redistributed most

72 of the described species at the time between them: Protohaustorius, Acanthohaustorius,

73 Pseudohaustorius, Neohaustorius, and Parahaustorius. After 1965, the only species that

74 remained in the nominal genus Haustorius were $H$. arenarius, the original type species, and $H$.

75 canadensis Bousfield, 1962 (Hancock \& Wicksten, 2018). These two would be joined later by $H$.

76 algeriensis Mulot, 1967 from Algeria, H. orientalis Bellan-Santini, 2005 from the

77 Mediterranean, H. jayneae Foster \& LeCroy, 1991 from the eastern Gulf of Mexico, $H$.

78 mexicanus Ortiz et al., 2001 from the state of Veracruz, Mexico, H. galvezi Hancock \&

79 Wicksten, 2018 from the western Gulf, and H. allardi Hancock \& Wicksten, 2018 from the

80 Mississippi Delta region. Among the haustoriids, the species within Haustorius are the largest by

81 body size, and they tend to inhabit the high intertidal zone on surf-exposed sandy beaches

82 (Hancock \& Wicksten, 2018; Hancock et al., 2019). The proposed sister to Haustorius is 
83 Lepidactylus, which looks remarkably similar to Haustorius except for the lack of an overhang

84 of epimeron 3 (Robertson \& Shelton, 1980; Hancock \& Wicksten, 2018). Hancock et al. (2019),

85 using four molecular markers, found support for Lepidactylus as sister to Haustorius, but this

86 work only included L. triarticulatus from the Gulf of Mexico and no other genera.

95 haustorioids by the presence of the "haustoriid-like" pereopod 5: greatly expanded and heavily

96 spinated. Those that did not then develop the "haustoriid-like" antenna were proposed to form a

97 clade consisting of the Urothoidea, Platyischnopidae, and Condukiidae (Barnard \& Drummond,

98 1982). Those that obtained the haustoriid antennae were then divided into two clades: 1) those

99 that lack a mandibular palp and glassy spines (the Phoxocephalidae) and 2) those with: the

100 Haustoriidae, Phoxocephalopsidae, Zobrachoidae, and the Urohaustoriidae.

A more recent phylogeny (Lowry \& Myers, 2017), based again on morphological

102 character states, proposed that the Haustoriidae are sister to the enigmatic Condukiidae, a family

103 endemic to Australia, while retaining the basal position of the Pontoporeiidae (with the addition

104 of an even more basal group, the Priscillinidae). However, Lowry \& Myers (2017) found no

105 support for a close relationship between the Zobrachoidae, Urohaustoriidae, 
Phoxocephalopsidae, and Haustoriidae; each of these families were scattered across the

107

108

109 Haustorioidea tree.

A recent large-scale molecular phylogeny of Amphipoda comes from Copilaş-Ciocianu et al. (2020) in which they used four markers to infer the relationships of 210 species across 102 families. In their phylogeny, the only haustoriid included, $H$. arenarius, is found to be a basal gammarid with high support as suggested by Barnard \& Drummond (1982) and in opposition to Lowry \& Myers (2017). In addition, Copilaş-Ciocianu et al. (2020) concluded that the Haustoriidira is a polyphyletic parvorder consisting of multiple families spread across at least two different suborders (Fig. 1c). The lack of monophyly likely represents intense convergent evolution to a predominately shallow-water benthic lifestyle, a habitat shared by all of the included families. Several studies prior to Copilaş-Ciocianu et al. (2020) also found H. arenarius to be a basal gammarid (Verheye et al., 2016; Hou \& Sket, 2017).

Lowry \& Myers (2017) and Myers \& Lowry (2018) have argued that molecular phylogenies that include some haustorioids tend to infer unprecedented relationships with little or no justification. For example, they note that $H$. arenarius is found to be the sister taxon to Salentinella (Bogidiellidae) in Verheye et al. (2016), a relationship that "During the three centuries that scientists have turned their attention to amphipod relationships, none of these associations have ever before been suggested” (Myers \& Lowry, 2018). Further, no large phylogeny of Amphipoda to date based on molecular techniques has included more than a single haustoriid (H. arenarius), which may indicate that incomplete taxon sampling or long-branch attraction are impacting inferred topologies.

The relationships within Haustoriidae were evaluated by Sweet (1996) using morphological traits (Fig. 1d). He determined that Protohaustorius was the most basal 
haustoriid; a finding also suggested by Bousfield (1965). This genus most resembles the phoxocephalids and is easily diagnosable from the other haustoriids by its geniculate first antenna. The next group proposed to branch-off was Neohaustorius spp. followed by Parahaustorius spp. Sweet (1996) inferred that Lepidactylus dysticus was the outgroup to the remaining two clades of haustoriids: the Haustorius group and a hodgepodge group consisting of Pseudohaustorius spp., Eohaustorius spp. (a Pacific-endemic genus), and Acanthohaustorius spp. Sweet's effort was the first and (prior to this work) only attempt at reconstructing a phylogeny of intrafamilial relationships of the Haustoriidae. Gulf of Mexico (Hancock et al., 2019). This study found support for widespread cryptic diversity among haustoriid species, and a range of species delimitation techniques identified at least 4 independent lineages within the nominal species L. triarticulatus. Hancock et al. (2020) followed this work by expanding sampling to haustoriid species endemic to the North Atlantic and the Pacific. However, this work focused specifically on the evolution of genome size within the

143 family and did not comment on the specific relationships inferred. coastline, which led Bousfield (1970) to postulate that the New England area was the center of

146 origin for the family. Since then at least two dozen species have been described from the Gulf of

147 Mexico (GoM) and Pacific coastlines, expanding the known distribution of haustoriids across the 148 northern hemisphere. In light of this, haustoriids may not have been a rapid radiation along the 149 North American coastline as Bousfield (1970) thought but may have begun to diversify long 150 before when the continents were in closer proximity (i.e., the Cretaceous or earlier). 
appearing rapidly following the separation of the continents and isolation of the Atlantic from the

153 Pacific Ocean, which had occurred by the Paleocene (56-61 Mya).

In this study, we examine three hypotheses concerning the phylogenetic affinity of

155 Haustoriidae: 1) the Haustoriidira (haustoriids and their kin) are basal gammarids (Barnard \&

156 Drummond, 1982; Fig. 1a); 2) the Haustoriidira are a sister group to the lysianassids (Lowry \&

157 Myers, 2017; Fig. 1b); and 3) that the Haustoriidira is polyphyletic, with families spread across

158 the Amphipoda (Verheye et al., 2016; Hou \& Sket, 2017; Copilaş-Ciocianu et al., 2020; Fig. 1c).

159 Finally, we provide taxonomic recommendations to aid in resolving incongruences between

160 molecular and morphological phylogenies of haustoriid amphipods. and is as follows:

Order Amphipoda Latreille, 1816 
Family Haustoriidae Stebbing, 1906

Genus Acanthohaustorius Bousfield, 1965*

Genus Eohaustorius Barnard, 1957*

Genus Haustorius Müller, 1775*

Genus Lepidactylus Say, 1818*

Genus Neohaustorius Bousfield, 1965*

Genus Parahaustorius Bousfield, 1965*

Family Ipanemidae Barnard \& Thomas, 1988

Family Otagiidae Hughes \& Lörz, 2013

Family Phoxocephalidae Sars, 1891*

Family Phoxocephalopsidae Barnard \& Drummond, 1982

Family Sinurothoidae Ren, 1999

Family Urohaustoriidae Barnard \& Drummond, 1982

196 All designations marked with "*” indicates that a member of the family or genus was included in 197 this study. 


\section{SAMPLE COLLECTION} and were preserved in 95\% ethanol. Eohaustorius estuarius from the Pacific coast was collected by Gary Buhler of Northwest Amphipod, LLC. Specimens from Japan were collected from three sites: 1) Nakusa-no-hama beach, Kemi, Wakayama City, Wakayama Prefecture; 2) Ustumi,

flame: $250 \mathrm{~mm}$, with front chain; products by RIGO Co., Ltd.) at high tide in the subtidal zone.

Samples were sieved through a $1 \mathrm{~mm}$ mesh and sorted in the field, then fixed and preserved in

$21170-99 \%$ ethanol. Eohaustorius sp. and additional samples of E. subulicola were collected by Aoi

212 Tsuyuki of Hokkaido University.

217 using an EZNA Tissue Kit (Omega Bio-tek Inc.) following the manufacturer's protocols.

218 Mitochondrial cytochrome oxidase I (COI) and nuclear 28S ribosomal RNA (28S) and histone

219 H3 (H3) were amplified via polymerase chain reaction (PCR). Primer sets and PCR conditions

220 for COI and $28 S$ follow Hancock et al. (2019); conditions for H3 follow Esmaeili-Rineh et al. 
(2015). Amplicons were verified using gel electrophoresis and we used ExoSAP-IT (Affymetric Inc.) to purify positive PCR products. Sanger sequencing on forward and reverse strands was performed at DNA Analysis Facility on Science Hill at Yale University. Sequences were manually edited in Sequencher v.4.10.1 (Gene Codes Corp.). three studies: Hancock et al. (2019), Hancock et al. (2020), and Copilaş-Ciocianu et al. (2020).

227 We subset the latter dataset (originally with 210 species) to include only the clades designated 228 "Gammaroids", "Miscellaneous", "Lysianassoids", and "Crangonyctoids", the last of which 229 acted as an outgroup (see Figure 1 in Copilaş-Ciocianu et al., 2020). Combined, these studies 230 include 95 species across 38 families, including 50\% of recognized haustoriid species and at 231 least one species for each described genus in the family (Table 1). We performed alignments 232 using MAFFT v7 (Katoh \& Standley, 2013) and checked COI and H3 in Mesquite 3.5

233 (Maddison \& Maddison, 2018) for the presence of premature stop codons. We found evidence of 234 saturation at the third codon position in COI (Fig. S1); this position was removed from 235 subsequent analyses. The final alignment length of COI was 458 bp; H3 was 376 bp; and $28 S$ was $1,799 \mathrm{bp}$; total alignment length of 2,633 bp. al. (2019), and we reduced the datasets to include only one individual per species. 
Phylogenetic inference was performed using two maximum-likelihood (ML) methods,

244 IQ-TREE v2.1.3 (Minh et al., 2020) and RAxML v.8 (Stamatakis, 2014), and a Bayesian

245 method, MrBayes (Huelsenbeck \& Ronquist, 2001). Phylogenetic analyses were performed on

246 the full concatenated dataset $(n=95)$ in which each gene was a separate partition. For the

247 protein-coding genes, we designated a GTR + I + G model of substitution; an HKY model was

248 set for $28 S$. These models were identified as the best model by PartitionFinder2 (Lanfear et al.,

249 2017). To assess node support in IQ-TREE, we performed 1,000 ultrafast bootstrap replicates

250 (UB) as well as the Shimodaira-Hasegawa approximate likelihood ratio test (SH-aLRT;

251 Shimodaira \& Hasegawa, 1999). In RAxML, we performed rapid bootstrapping under the

252 GTRCAT model with 1,000 replicates. For our Bayesian analysis in MrBayes, we designated a

253 Birth-Death tree prior and ran two independent MCMC chains of 10 million generations each

254 with a $25 \%$ burn-in to ensure ESS values $>200$. Consensus trees were generated using the

255 command sumtrees in DendroPy (Sukumaran \& Holder, 2010).

A large number of sequences failed the composition $\chi^{2}$ test (41 sequences, $\sim 43 \%$ )

257 implemented in IQ-TREE, and 50 sequences $(\sim 52 \%)$ had missing data $>50 \%$. This was due to a

258 combination of large gaps in some of the aligned $28 S$ sequences and some samples lacking a $28 S$

259 sequence altogether. Thus, we performed the above methods on a reduced dataset that only

260 contained those that passed the composition $\chi^{2}$ test $(n=54)$ to evaluate how missing data may be

261 impacting our results.

To investigate relationships within the Haustoriidae, we performed species-tree inference

263 using BPP (Rannala \& Yang, 2003). A guide-tree was produced using IQ-TREE on the reduced

264 haustoriid-only dataset. Tree search was performed using subtree pruning and regrafting (SPR),

265 and the MCMC was run for 200,000 generations sampling every 2 generations with a 10,000 
generation burn-in. We then generated a maximum-clade credibility tree from the set of trees produced during the MCMC using the command sumtrees in DendroPy. Sweet (1996) of the Haustoriidae. We altered the original matrix by removing traits specific to the outgroup and any apomorphic trait. We additionally modified some trait scores to align with

271 identified taxonomically important traits from Hancock \& Wicksten (2018). The cladogram was

272 inferred by a heuristic search of the 100 most parsimonious trees in Mesquite. Tree-space was

273 searched using SPR. A majority-rule consensus tree was generated from the 100 trees.

283 priors to the age of the Crangonyctidae-Pseudocrangonyctidae and the Niphargidae-

284 Pseudoniphargidae splits according to Baltic amber fossils from the Eocene as 38-215 Mya. We

285 then set exponential priors on splits within the Haustoriidae based on Hancock et al. 2020: 1) the 286 proposed closure of the Okefenokee Trough 1.75 Mya (set as 1.55-4.5 Mya; Bert, 1986; Avise,

287 1992; Knowlton \& Weigt, 1998); and 2) the hypothesized Pleistocene colonization of Europe by 


\section{ANCESTRAL HABITAT AND MORPHOLOGY RECONSTRUCTION} 2012). We focus on the following traits that have emerged in the literature as being informative at the genus level: 1) epimeron 3 overhangs the urosome (1) or not (0); 2) maxilla 2 outer plate the same size (0), slightly larger (1), or twice as large as the inner (2); 3) presence (1) or absence (0) of a lobe on article 5 of pereopod $6 ; 4$ ) number of spine groups on the posterior margin of article 4 on pereopod 7: 1, 2, 3, or 4; and 5) telson is uncleft (0), marginally cleft (1), or cleft to 299 the base (2). they occurred on the open coast ("open") or in brackish estuaries ("bay"). Furthermore, we searched for phylogenetic trends related to bottom preference: 1) fine sand; 2) medium/coarse sand; and 3) mud. Finally, we reconstructed the ancestral state of whether species occurred in the intertidal zone or subtidally. The complete table with character states, habitat information, and sample location can be found in the supplementary materials (Table S1). 
2). We found that this result was not influenced by missing data as the reduced analysis also

313 found this relationship (with even stronger support, Fig. S2-5). Furthermore, we found that the

314 other families assigned to Haustoriidira that were included in our analyses (Pontoporeiidae,

315 Phoxocephalidae, and Urothoidae) showed no affinity to the true haustoriids (Fig. 2). Instead,

316 these families were found to be basal lysianssids (Pontoporeiidae, along with Bathyporeiidae) or

317 belonged to clades independent of both the lysianassids and the gammaroids (i.e.,

318 Phoxocephalidae and Urothoidae).

The BPP analysis found that the type-genus Haustorius is paraphyletic with respect to Lepidactylus with high support $(\mathrm{PP}=1.0)$, with L. dysticus grouping with the Haustorius species

321 endemic to the GoM. The GoM endemic Lepidactylus - the L. triarticulatus species complex -

322 was monophyletic, but distantly related to the L. dysticus + GoM endemic Haustorius clade (Fig.

323 3). The remaining Haustorius species, H. canadensis and H. arenarius, were found to be sister

324 taxa and an outgroup to the aforementioned clades. The relationships between this "Haustorius-

325 Lepidactylus" clade and the remaining genera remains uncertain due to relatively low node

326 support $(\mathrm{PP}<0.6)$. However, we did recover the monophyly of the remaining genera (except for

327 Protohaustorius) and found strong support for the Pacific-endemic genus, Eohaustorius, as the

328 earliest split from the other haustoriids.

329 The parsimony tree produced from the character matrix generally recapitulated the results

330 from BPP, with a few exceptions (Fig. 3a). BPP inferred Neohaustorius and Acanthohaustorius

331 as being closer to the "Haustorius-Lepidactylus" clade than the character matrix supported, and

332 that L. dysticus belonged to a clade consisting of Parahaustorius and Protohaustorius. This tree

333 also differed somewhat from Sweet (1996), which inferred Protohaustorius as the most basal

334 haustoriid. 

genus, Eohaustorius, and the remaining haustoriids followed shortly thereafter $\sim 37$ Mya (27-51

341 Mya, 95\% HPD) during the Eocene. The East Asian Eohaustorius species were cut off from the

342 North American continent by 25 Mya (16-37 Mya, 95\% HPD). Further, we find evidence that

343 the GoM was independently colonized by different genera of haustoriids at different times. The

344 Pseudohaustorius americanus split is the deepest that includes a GoM endemic ( 32 Mya), but

345 without its Atlantic relatives we cannot conclude how long ago it colonized the Gulf. However,

346 we do find that the ancestors of Parahaustorius obliquus split from its Atlantic-endemic relatives

$347 \sim 16$ Mya, which makes it the earliest known colonization. The most abundant GoM endemics are

348 those that appear to have colonized the Gulf most recently, within the last 10 million years: the

349 Acanthohaustorius, Haustorius, and L. triaticulatus species groups. The most recent

350 colonizations likely postdate the divergence of $H$. canadensis and $H$. arenarius, sister species

351 separated on either side of the Atlantic ( $9.5 \mathrm{Mya})$. Finally, we find that among the GoM-

352 endemics, the deepest splits occur on opposite sides of the Mississippi River and likely occurred

353 during the Pliocene or the end of the Miocene (2-7 Mya for H. jayneae and H. galvezi; 4-11

354 Mya for L. triarticulatus (GI-SR) and L. triarticulatus (PB-PC2)). 
Ancestral range reconstructions indicated that haustoriids were likely originally subtidal species in the open ocean, and that the transition to the intertidal zone occurred twice: in Eohaustorius in the Pacific and in the Haustorius-Lepidactylus clade in the Atlantic (Fig. 5).

361 Furthermore, we find that there were likely four independent shifts to brackish waters: $E$. estuarius in the eastern Pacific, L. triarticulatus complex in the GoM, L. dysticus in the Atlantic, and $H$. allardi in the Louisiana delta region (Fig. 5). In addition, the ancestral bottom preference was likely fine sand, with the Atlantic and eastern GoM endemics independently colonizing coarse sand (Fig. S9).

All reconstructed character traits were homoplastic to varying degrees (Fig. S6-8). the genus level (Fig. S7b, S8a). The size of the inner lobe of maxilla 2 relative to the outer was an inferred ancestral state for a Pseudohaustorius-Eohaustorius-Protohaustorius clade but may

370 have arisen secondarily in Neohaustorius as well. The other two states of this character show

371 little phylogenetic conservation and may not represent two distinct traits at all (i.e., they may be 372 quantitative). The hooked state of epimeron 3 also supported this clade but there is a secondary 373 loss of the hook in Protohaustorius. 
In support of previous molecular phylogenies (Hou \& Sket, 2016; Copilaş-Ciocianu et al., 2020), we find that haustoriid amphipods are basal gammarids and that there is no molecular support for the "Haustoriidira" parvorder (Lowry \& Myers, 2017). Furthermore, we find that haustoriids in the Atlantic are monophyletic relative to those in the Pacific and likely diverged >31 Mya. Finally, we find that the type-genus, Haustorius, is paraphyletic with respect to Lepidactylus. To resolve this issue, we recommend reserving Haustorius to Atlantic-specific species, placing the GoM-endemic "Haustorius" species within Lepidactylus, and elevating the GoM-endemic L. triarticulatus species complex to a new genus, Cryptohaustorius. Myers (2017) noted that most guides present families in alphabetical order instead of phylogenetically. Several recent large-scale studies of amphipods have attempted to remedy this issue (Englisch et al., 2003; Havermans et al., 2010; Lowry \& Myers, 2017; Hou \& Sket, 2017; Copilaş-Ciocianu et al., 2020). In terms of the taxonomic placement of the Haustoriidae, a consensus has begun to emerge in molecular phylogenies of the group as basal gammarids 398 (Englisch et al., 2003; Hou \& Sket, 2017). These phylogenies have been contested by Lowry \& 399 Myers (2017) and Myers \& Lowry (2018), who have argued that molecular phylogenies are "not 400 built on any previous hypotheses" and are "not falsifiable". 
monophyletic parvorder within the infraorder Lysianassida (see Taxonomy in Methods above).

405

406

407

408

409

410

411

412

413

414

415

416

417

418

419

420

421

422

423

424

425

426

We find strong evidence that haustoriid amphipods are not related to the lysianassids but are instead basal gammarids as was proposed by Barnard \& Drummond (1982). However, in opposition to Barnard \& Drummond (1982) we find no support for the monophyly of the Haustorioidea; instead, the families generally allied in this group were found distributed across the amphipod phylogeny (Fig. 2). However, we have included far fewer members of the families outside Haustoriidae, and many families within the Haustoriidira are not represented in our phylogeny at all. Indeed, the vast majority have never been sequenced. Of special note is the lack of sequence data from the proposed sister to the Haustoriidae, the Condukiidae, and other Australian endemic families (i.e., Urohaustoriidae and the Zobrachoidae). Therefore, we can make no definitive statement as to the placement of these other families within the Amphipoda. 
427 followed by a period of rapid cooling (Ivany et al., 2000). This extinction event may have freed

428 the coastal niche to new inhabitants, which was quickly exploited by the ancestors of the

429 Haustoriidae. Furthermore, given that this event was followed by a period of cooling, it may help

430 to explain the preference of haustoriid amphipods to cooler temperate climates. For example,

431 haustoriid amphipods are largely absent from tropical areas in the Caribbean and South America

432 despite the abundance of sandy beaches in these regions. Other explanations exist; for example,

433 these niches may already have been filled by various species of mole crab (e.g. Emerita

434 portoricensis) and isopods (e.g. Exirolana spp.), which are highly abundant in these regions 435 (pers. obs.).

437 least 4 separate occasions. The most abundant haustoriids are the intertidal species belonging to

438 the genera Lepidactylus and Haustorius, which independently colonized the Gulf 6-15 Mya.

439 Much of the Gulf states were submerged during this time as Pliocene sea levels were higher than

440 they are today (Avise, 1992). The closing of the Isthmus of Panama during this epoch

441 represented a dramatic alteration in the current regime as it forced the Loop Current over the

442 submerged panhandle of modern Florida (Knowlton \& Weigt, 1998). This increased oceanic

443 current may have contributed to the divergence between Gulf and Atlantic species as has been

444 proposed for many other coastal fauna (see Avise, 1992; Portnoy \& Gold, 2012). Furthermore,

445 multiple vicariant zones are known to exist within the GoM and have been proposed to explain

446 divergence between sister taxa often separated by the Mississippi River or Mobile Bay (Portnoy

$447 \&$ Gold, 2012; Hancock et al., 2019). These include the influx of freshwater down the Tennessee

448 River 2.4 Mya into Mobile Bay, the Suwannee Straits over northern Florida $\sim 1.7$ Mya, and 
449 increased sedimentation during the Miocene 5-10 Mya (Simpson, 1900; Bert, 1986; Portnoy \& 450 Gold, 2012; Hancock et al., 2019).

The Pacific-endemic haustoriid genus, Eohaustorius, diverged from the Atlantic group

$452 \sim 31$ Mya (Fig. 2). The only species included in our phylogeny endemic to the western coastline

453 of North America is E. estuarius, and it diverged from its western Pacific relatives $\sim 25$ Mya. In

454 the western Pacific, E. subulicola was originally described from Japan (Hirayama, 1985),

455 whereas E. longidactylus was first collected on the Korean peninsula (Jo, 1990). We collected

456 both species on the Banzu tidal flats in Chiba, Japan. This could indicate that these species have

457 historically been distributed across both Japan and the Korean peninsula; alternatively, the

458 distribution could represent a secondary migration event after previously being separated by the

459 Tsushima Straits (Takada et al., 2018). Indeed, these two species diverged 2.5 Mya, which

460 corresponds to the opening of the straits (Kitamura \& Kimoto, 2006). During the Pleistocene

$461(\sim 10,000$ years ago $)$, a glacial maximum reconnected the Korean peninsula and Japan

462 temporarily and could have facilitated secondary contact. On the other hand, in the Kisarazu

463 region (including Banzu tidal flat) more than 1,800 tons of Ruditapes philippinarum (seed clams)

464 are transplanted every year, but the source of the clams is not identified (Toba, 2002). Kitada et

465 al. (2013) pointed out that large quantities of seed clams continue to be brought into Tokyo Bay

466 from China. Okoshi (2004) reported that 22 species of marine benthic invertebrates were

467 transported to Japan from Korean peninsula and Eastern China along with living clams.

468 Therefore, further study is needed to determine whether E. longidactylus is native to Japan or

469 was recently introduced by human shipping practices. 
474 taxonomic rearrangements: 1) the genus name "Haustorius" is relegated to H. canadensis and the

475 eastern Atlantic species; 2) GoM endemic "Haustorius" species represent a radiation of $L$.

476 dysticus into the Gulf and therefore we suggest that these species should all be placed within the

477 genus Lepidactylus; 3) the "L. triarticulatus" species complex is a distinct sister group to

478 Lepidactylus, and we elevate this grouping to a new genus, Cryptohaustorius.

479

GENUS HAUSTORIUS MÜLLER, 1775 WITH THE TYPE SPECIES HAUSTORIUS

482 Diagnosis

483 Large haustoriids restricted to open coasts in the Atlantic and Mediterranean. Maxilla 2 outer

484 lobe is narrow and lanceolate, more than twice the size of the inner lobe. Pleon overhangs the 485 urosome, with epimeron 3 smooth and ventrally curved (without hook). Telson cleft emarginate.

486 Known species: H. arenarius, H. canadensis, H. algeriensis, H. orientalis, H. mexicanus*

487 *The status of H. mexicanus is unclear. If a true Haustorius (in our definition above), it would 488 represent the only Haustorius in the GoM. However, we have been unable to obtain specimens 489 of this species and have not located it at its type locality.

491 GENUS LEPIDACTYLUS SAY, 1818 WITH THE TYPE SPECIES LEPIDACTYLUS 
494 Small to medium size haustoriids in the GoM and Atlantic coastlines. May be found on open

495 coasts or in brackish bays. Maxilla 2 outer lobe is narrow and lanceolate (except in L. allardi),

496 and roughly twice the size of the inner lobe. Baler lobe on maxilliped is weakly developed. Pleon

497 slightly overhangs the urosome, with epimeron 3 smooth and ventrally curved (without hook).

498 Telson cleft emarginate or to base.

499 Known species: L. dysticus, L. jayneae, L. galvezi, L. allardi

500

504 Small haustoriids $(2-5 \mathrm{~mm})$ restricted to the GoM. These are most numerous in brackish bays

505 but may be found in small numbers subtidally on open coasts. Maxilla 2 outer lobe is broadly

506 expanded and roughly twice the size of the inner lobe. Pleon is continuous with the urosome,

507 with epimeron 3 smooth and ventrally curved (without hook). Telson cleft to the base, strongly

508 spinated.

509 Etymology: From New Latin, the prefix "crypto" means "hidden" and the suffix "haustorius" is

510 the type genus of the family.

511 Known species: C. triarticulatus (undescribed species complex; Hancock et al., 2019)

512 Type locality: Malaquite Beach, Texas

513 Known range: Northwestern Gulf of Mexico to at least Carrabelle Beach, Florida 
517 Parahaustorius clade. However, without additional members of the genus and with low

518 confidence of the phylogenetic position of Pr. bousfieldi, we suggest that additional data is

519 needed before taxonomic reorganization is necessary.

\section{CONCLUSIONS}

524 attention in recent decades. While considerable work remains to be done on the higher taxonomy

525 of Amphipoda, it is now clear that the haustoriids are not relatives of the lysianassids. Instead,

526 they represent an early split from gammaridean amphipods. Furthermore, other fossorial

527 amphipods with similar morphology do not appear to be immediate relatives of the haustoriids,

528 suggesting widespread convergence on traits ideal for a sand-dwelling lifestyle. Similarly, we

529 find that most of the traits commonly used in dichotomous keys to distinguish the genera of

530 haustoriids are homoplastic, suggesting need for systematic revision of taxonomically

531 informative traits in Haustoriidae.

532 Future work should expand taxon sampling to the Australian-endemic "haustorioids",

533 such as the condukiids and the urohaustoriids, as well as include more representative members of

534 other families within the "parvorder". In addition, these phylogenies would benefit greatly from

535 increased molecular resources including next-generation sequencing. A more exhaustive

536 phylogeny of the fossorial amphipods may permit larger trait reconstructions to identify the

537 timing of convergence to both phenotypes and habitat. 
While the deconstruction of a taxonomic hypothesis in the absence of proposing a new

539

540

541

542

543

544 Special thanks to Gary Buhler and Aoi Tsuyuki for providing material for this study, and Denis

545 Copilaş-Ciocianu of the Nature Research Centre in Lithuiana for sharing his alignments with us.

546

547

548

549

550

551

552

553

554

555

556

557

558

559

560

561

562

563

higher classification scheme may seem like a step backwards, we contend that such a step is necessary to shed light on one of the many amphipod mysteries: the origin of the Haustoriidae.

\section{ACKNOWLEDGEMENTS}

Comments provided by Masanori of the Tokyo Bay Ecosystem Research Center has been a great help in this study. We are also particularly grateful to Dr. Hiroyuki Ariyama of Osaka Museum of Natural History and Yo Asada of Gifu University for advice on collection sites. We would also like to thank the many people who helped us collect in the field: Faith O. Hardin, Thomas Strawn, Shelby Strawn, Janelle Goeke and Justin Hilliard of Texas A\&M University-Galveston, and Nuri Ubach, Sergio “Tama” Rodríguez, Jose "Pepe” Salgado, all of Unidad Académica Mazatlán, at the Instituto de Cinecias del Mar y Limnología, UNAM. This work was funded by grants from the Ecology \& Evolutionary Biology (EEB) program at Texas A\&M University, Texas Sea Grant, and Texas Ecolabs.

Avise JC. 1992. Molecular population structure and the biogeographic history of a regional fauna: A case history with lessons for conservation biology. Oikos 62(1): 62-76.

Barnard JL. 1957. A new genus of haustoriid amphipod from the north-eastern Pacific Ocean, and the southern distribution of Urothoe varvarini. Bulletin of the Southern California Academy of Science 56(2): 81-84. 
Barnard JL. 1969. The Families and Genera of Marine Gammaridean Amphipoda. Washington, DC: Smithsonian Institution Press.

Barnard JL, Drummond MM. 1979. Gammaridean Amphipoda of Australia, Part IV. Smithsonian Contributions to Zoology 269(I-III): 1-69.

Barnard JL, Drummond MM. 1982. Gammaridean Amphipoda of Australia, Part V. Washington, DC: Smithsonian Institution Press.

Barnard JL, Thomas JD. 1988. Ipanemidae, new family, Ipanema talpa, new genus and species, from the surf zone of Brazil (Crustacea: Amphipoda: Haustorioidea). Proceedings of the Biological Society of Washington 101(3): 614-621.

Bellan-Santini D. 2005. European species of Haustorius (Crustacea: Amphipoda: Haustoriidae), with description of a new Mediterranean species. Journal of Natural History 39(15): 1101-1110.

Bert TM. 1986. Speciation in western Atlantic stone crabs (genus Menippe): the role of geological processes and climatic events in the formation and distribution of species. Marine Biology 93: 157-170.

Boeck A. 1871. Crustacea Amphipoda Borealia et Arctica. Forhandlinger i VidenskabsSelskabet i Christiania 83-280.

601

Bousfield EL. 1962. New haustoriid amphipods from the Canadian Atlantic region. Bulletin of the National Museum of Canada 183: 63-75.

Bousfield EL. 1965. Haustoriidae of New England (Crustacea: Amphipoda). Proceedings of the United States National Museum 117(3512): 159-239.

Bousfield EL. 1970. Adaptive radiation in sand-burrowing amphipod crustaceans. Chesapeake Science 11(3): 143-154.

Bousfield EL. 1978. A revised classification and phylogeny of amphipod crustaceans. Royal Society of Canada 4: 343-390.

Copilaş-Ciocianu D, Borko S, Fišer C. 2020. The late blooming amphipods: Global change promoted post-Jurassic ecological radiation despite Palaeozoic origin. Molecular Phylogenetics and Evolution 143: 106664.

Dana JD. 1849. Synopsis of the genera of Gammaracea. American Journal of Science and Arts 2: 135-140.

Dana JD. 1852. On the classification of the Crustacea Chrostopoda or Tetradecapoda. American Journal of Sciences and Arts 2(14): 297-317. 
610 Derzhain AN. 1927. Notes on the Upper Sarmatian Amphipods of the Ponto-Caspian region.

611 Bulletin de la Societe des Naturalistes de Moscou 2: 183-196.

612

613

614

615

616

617

618

619

620

621

622

623

624

625

626

627

628

629

630

631

632

633

634

635

636

637

638

639

640

641

642

643

644

645

646

647

648

649

650

651

652

653

654
d'Udekem d'Acoz C. 2006. Systematic, phylogenetic and biological considerations on the genera Bathyporeia, Amphiporeia, Pontoporeia and Priscillina, with redescription of the West-Atlantic Bathyporeia species and description of a new Priscillina from Svalbard (Crustacea, Amphipoda). Bulletin de L'Institut Royal Des Sciences Naturelles de Belgique Biologie 76: 33-110.

Englisch U, Coleman CO, Wägele JW. 2003. First observations on the phylogeny of the families Gammaridae, Crangonyctidae, Melitidae, Niphargidae, Megaluropidae and Oedicerotidae (Amphipoda, Crustacea), using small subunit rDNA gene sequences. Journal of Natural History 37(20): 2461-2486.

Esmaeili-Rineh S, Sari A, Delić T, Moškrič A, Fišer C. 2015. Molecular phylogeny of the subterranean genus Niphargus (Crustacea: Amphipoda) in the Middle East: a comparison with European Niphargids. Zoological Journal of the Linnean Society 175(4): 812-826.

Foster JM, LeCroy SE. 1991. Haustorius jayneae, a new species of haustoriid amphipod from the northern Gulf of Mexico, with notes on its ecology at Panama City Beach, Florida. Gulf Research Reports 8(3): 259-270.

Hancock ZB, Wicksten MK. 2018. Two new species of sand-burrowing amphipods of the genus Haustorius Müller, 1775 (Amphipoda: Haustoriidae) from the northwestern Gulf of Mexico. Zootaxa 4459(1): 101-127.

Hancock ZB, Hardin FO, Light JE. 2019. Phylogeography of sand-burrowing amphipods (Haustoriidae) supports an ancient suture zone in the Gulf of Mexico. Journal of Biogeography 46(11): 2532-2547.

Hancock ZB, Hardin FO, Murthy A, Hillhouse A, Johnston JS. 2020. Rapid genomic expansion and purging associated with habitat transitions in a clade of beach transitions (Haustoriidae: Amphipoda). bioRxiv doi: https://doi.org/10.1101/2020.08.26.268714.

Havermans C, Zoltán TN, Sonet G, De Broyer C, Martin P. 2010. Incongruence between molecular and morphological classification in amphipod crustaceans: A case study of Antarctic lysianassoids. Molecular Phylogenetics and Evolution 55: 202-209.

Hirayama A. 1985. Taxonomic Studies on the Shallow Water Gammaridean Amphipoda of West Kyushu, Japan -IV. Dexaminidae (Guernea), Eophiliantidae, Eusiridae, Haustoriidae, Hyalidae, Ischyroceridae. Publications of the Seto Marine Biology Laboratory 30(1-3): 1-53.

Hou Z, Sket B. 201. A review of Gammaridae (Crustacea: Amphipoda): the family extent, its evolutionary history, and taxonomic redefinition of genera. Zoological Journal of the Linnean Society 176: 323-348. 
Huelsenbeck JP, Ronquist F. 2001. MRBAYES: Bayesian inference of phylogenetic trees. Bioinformatics Applications Note 17(8): 754-755.

Hughes L, Lörz AN. 2013. Family placement of the enigmatic Otagia neozelanica (Chilton, 1897) Haustorioidea: Otagiidae fam. nov. (Amphipoda: Crustacea). Zootaxa 3636(3): 439-450.

Ivany LC, Patterson WP, Lohman KC. 2000. Cooler winters as a possible cause of mass

Jo YW. 1990. Four new species of sand-burrowing haustoriid Amphipoda (Crustacea) of Korea. Bulletin Zoölogisch Museum 12(9): 117-144.

Katoh K, Standley DM. 2013. MAFFT multiple sequence alignment software version 7:

Improvements in performance and usability. Molecular Biology and Evolution 30(4): 772-780.

Kitada S, Fujikake,C, Asakura Y, Yuki H, Nakajima K, Vargas KM, Kawashima S, Hamasaki K, Kishino H. 2013. Molecular and morphological evidence of hybridization between native Ruditapes philippinarum and the introduced Ruditapes form in Japan. Conservation Genetics 14: $717-733$.

Kitamura A, Kimoto K. 2006. History of the inflow of the warm Tsushima Current into the Sea of Japan between 3.5 and 0.8 Ma. Palaeogeography, Palaeoclimatology, Palaeoecology 236(34): 355-366.

Knowlton N, Weigt LA. 1998. New dates and new rates for divergence across the Isthmus of Panama. Proceedings of the Royal Society B 265(1412): 2257-2263.

Lanfear R, Frandsen PB, Wright AM, Senfeld T, Calcott B. 2017. PartitionFinder2: New methods for selecting partitioned models of evolution for molecular and morphological phylogenetic analyses. Molecular Biology and Evolution 34(4): 772-773.

Latreille PA. 1816. Amphipoda. In: Nouveau Dictionaire d'histoire naturelle, appliquée aux Arts, à l'Agriculture, à l'Économie rurale et domestique, à la Médecine, etc. Par une société de Naturalistes et d'Agriculteurs. 2nd Edition. Vol. 1. Deterville, Paris, 467-469.

LeCroy SE. 2002. An Illustrated Identification Guide to the Nearshore Marine and Estuarine Gammaridean Amphipoda of Florida, Vol. 2. Tallahassee: State of Florida Department of Environmental Protection.

698

Lowry JK, Myers AA. 2013. A Phylogeny and Classification of the Senticaudata subord. nov. (Crustacea: Amphipoda). Zootaxa 3610(1): 1-80.

Lowry JK, Myers AA. 2017. A phylogeny and classification of the Amphipoda with the 699 establishment of the new order Ingolfiellida (Crustacea: Peracarida). Zootaxa 4265(1): 1-89. 
Maddison WP, Maddison DR. 2018. Mesquite: A modular system for evolutionary analysis.

Version 3.51. Retrieved from http://www.mesquiteproject.org.

Minh BQ, Schmidt HA, Chernomor O, Schrempf D, Woodhams MD, von Haeseler A, Lanfear R. 2020. IQ-TREE 2: New models and efficient methods for phylogenetic inference in the genomic era. Molecular Biology and Evolution 37(5): 1530-1534.

Müller PLS. 1775. Des Ritters Carl von Linné (...) vollständiges Natursystem nach der zwölften lateinischen Ausgabe und nach Anleitung des holländischen Houttuynischen Werks mit einer ausführlichen Erklärung. Sechster Theil. Von den Würmern. Erster Band. Nebst neunzehn Kupfertafeln, Nürnberg, $15+638$ pp., 19 tabs.

Mulot M. 1967. Description of d'Haustorius algeriensis n. sp. (Amphipoda: Haustoriidae). Bulletin de la Société zoologique de France 92(4): 815-826.

Myers AA, Lowry JK. 2018. The Senticaudata, a suborder of the Amphipoda - A commentary on d'Udekem d'Acoz and Verheye (2017). ZooKeys 730: 151-155.

Okoshi K. 2004. Alien species introduced with imported clams: the clam-eating moon snail Euspira fortunei and other unintentionally introduced specie. Japanese Journal of Benthology 59: 74-82. (In Japanese)

Ortiz M, Chazaro-Olvera S, Winfield I. 2001. A new amphipod crustacean of the genus Haustorius (Gammaridea, Haustoriidae), from the east coast of Mexico. Avicennia 14: 53-59.

Portnoy D, Gold JR. 2012. Evidence of multiple vicariance in a marine suture-zone in the Gulf of Mexico. Journal of Biogeography 39: 1499-1507.

Rannala B, Yang Z. 2003. Bayes estimation of species divergence times and ancestral population sizes using DNA sequences from multiple loci. Genetics 164(4): 1645-1656.

Ren X. 1999. A new family of superfamily Haustoroidea [sic] (Crustacea: Amphipoda:

Gammaridea) from the China Sea. Chinese Journal of Oceanology and Limnology 17(4): 344349.

Revell LJ. 2012. phytools: an R package for phylogenetic comparative biology (and other things). Methods in Ecology and Evolution 3: 217-223.

Robertson PB, Shelton CR. 1980. Lepidactylus triarticulatus n. sp., a new haustoriid amphipod from the northern Gulf of Mexico. Gulf Research Reports 6(4): 415-420.

Sars GO. 1891. An account of the Crustacea of Norway, with short descriptions and figures of all the species, Vol. I. Amphipoda. Phoxocephalidae. Cammermeyers, Christiania and Copenhagen, 69-212. 
Say T. 1818. An account of the Crustacea of the United States. Journal of the Academy of Natural Sciences of Philadelphia 1(1): 374-401.

Shimodaira H, Hasegawa M .1999. Multiple comparisons of log-likelihoods with applications to phylogenetic inference. Molecular Biology and Evolution 16(8): 1114-1116.

Simpson CT 1900. On the evidence of the Unionidae regarding the former courses of the Tennessee and other southern rivers. Science 12(291): 133-136.

Slabber M. 1769. Natuurkundige verlustigingen, behelzende microscopies waarneemingen van de in- en uitlandse water- en land-dieren. Bibliotheek Rotterdam.

Stamatakis A. 2014. RAxML Version 8: A tool for phylogenetic analysis and post-analysis of Sohn verlag.

Sukumaran J, Holder MT. 2010. DendroPy: A Python library for phylogenetic computing. Bioinformatics 26: 1569-1571.

Sweet MH. 1996. The Evolution of the Haustorioidea of the World, and Post-Embryonic Development, Taxonomy and Ecology of the Haustoriidae (Amphipoda: Crustacea). College Station, TX: PhD Dissertation, Department of Biology, Texas A\&M University.

Takada Y, Sakuma K, Fujii T, Kojima S. 2018. Phylogeography of the sandy beach amphipod Haustorioides japonicus along the Sea of Japan: Paleogeographical signatures of cryptic divergences. Estuarine, Coastal and Shelf Science 200: 19-30.

Thurston MH. 1982. Cheus annae, new genus, new species (Cheidae, new family), a fossorial amphipod from the Falkland Islands. Journal of Crustacean Biology 2(3): 410-419.

Toba M. 2002. Present Status of the Fishery for the Clam Ruditapes philippinarum in Chiba Prefecture, Tokyo Bay. Japanese Journal of Benthology 57:145-150. (In Japanese) homoplasy in taxonomically important morphological characters of Eusiroidea (Crustacea, Amphipoda). Zoological Scripta 45(3): 300-321. 
TABLE AND FIGURE CAPTIONS

786

787 Table 1. Haustoriid species included in this study.

788

789

Figure 1. Phylogenetic hypotheses. a) basal gammarid hypothesis (Barnard \& Drummond 1982);

790

b) lysianassid hypothesis (Lowry \& Myers 2017); c) convergent hypothesis; d) hypothesis of

791 relationships within Haustoriidae (Sweet 1996); e) Haustorius galvezi; f) pereopod 6 article 5,

792 arrow indicates taxonomically significant notch; g) maxilla 2 outer lobe compared to size of

793 inner lobe (smaller, bottom).

794

795 Figure 2. Maximum-likelihood phylogeny of Amphipoda from IQ-TREE.

797 Figure 3. Species tree of Haustoriidae from BPP. Colors represent nominal genera. a) cladogram

798 from the character matrix, colored clades match those from the species tree; b) species tree

799 produced from BPP; c) Haustorius allardi; d) dorsal view of rostrum from Haustorius galvezi.

800

801 Figure 4. Time-calibrated phylogeny from BEAST2. Green diamonds represent calibration

802 points: 1) closure of the Okefenokee Trough (1.75 Mya); 2) proposed migration to Europe by $H$.

803 arenarius ( $~ 5 \mathrm{Mya})$; 3) Pontocaspian gammarid clade radiation (9-83 Mya); 4) Niphargidae-

804 Pseudoniphargidae split (38-215 Mya); 5) Crangonyctidae-Pseudocrangonyctidae split (38-215

805 Mya).

806 
807 Figure 5. Ancestral habitat reconstructions. a) shifts between subtidal and intertidal; b) shifts

808 between open and brackish coastlines. "L. tri" is short for L. triarticulatus, with initials following 809 representing the lineage.

\begin{tabular}{|c|c|c|c|c|}
\hline Genus & species & $\begin{array}{l}\text { Original } \\
\text { description }\end{array}$ & Range & $\begin{array}{l}\text { Percent of } \\
\text { genus* }\end{array}$ \\
\hline Haustorius & arenarius & Slabber, 1769 & Northern Europe & \multirow[t]{5}{*}{$71 \%$} \\
\hline Haustorius & canadensis & Bousfield, 1960 & Western Atlantic & \\
\hline Haustorius & jayneae & $\begin{array}{l}\text { Foster \& } \\
\text { LeCroy, } 2001\end{array}$ & $\begin{array}{l}\text { Eastern Gulf of } \\
\text { Mexico }\end{array}$ & \\
\hline Haustorius & galvezi & $\begin{array}{l}\text { Hancock \& } \\
\text { Wicksten, } 2018\end{array}$ & $\begin{array}{l}\text { Western Gulf of } \\
\text { Mexico }\end{array}$ & \\
\hline Haustorius & allardi & $\begin{array}{l}\text { Hancock \& } \\
\text { Wicksten, } 2018\end{array}$ & $\begin{array}{l}\text { Mississippi Delta } \\
\text { region }\end{array}$ & \\
\hline Lepidactylus & triarticulatus $^{\dagger}$ & $\begin{array}{l}\text { Robertson \& } \\
\text { Shelton, } 1980\end{array}$ & Gulf of Mexico & \multirow[t]{2}{*}{$100 \%$} \\
\hline Lepidactylus & dysticus & Say, 1818 & Western Atlantic & \\
\hline Protohaustorius & bousfieldi & $\begin{array}{l}\text { Robertson \& } \\
\text { Shelton, } 1978\end{array}$ & Gulf of Mexico & \multirow[t]{2}{*}{$66 \%$} \\
\hline Protohaustorius & deichmanne & Bousfield, 1965 & Western Atlantic & \\
\hline Acanthohaustorius & millsi & Bousfield, 1965 & Western Atlantic & \multirow[t]{2}{*}{$12 \%$} \\
\hline Acanthohaustorius & sp. A & LeCroy, 2002 & $\begin{array}{l}\text { Western Gulf of } \\
\text { Mexico }\end{array}$ & \\
\hline Eohaustorius & estuarius & Bosworth, 1973 & Eastern Pacific & \multirow[t]{4}{*}{$25 \%$} \\
\hline Eohaustorius & setulosus & Jo, 1990 & Korea, Japan & \\
\hline Eohaustorius & subulicola & Hirayama, 1985 & Korea, Japan & \\
\hline Eohaustorius & longidactylus & Jo, 1990 & Korea, Japan & \\
\hline
\end{tabular}




\begin{tabular}{|c|c|c|c|c|}
\hline Neohaustorius & schmitzi & Bousfield, 1965 & Western Atlantic & $50 \%$ \\
\hline Parahaustorius & holmesi & Bousfield, 1965 & Western Atlantic & \multirow[t]{3}{*}{$75 \%$} \\
\hline Parahaustorius & longimerus & Bousfield, 1965 & Western Atlantic & \\
\hline Parahaustorius & obliquus & $\begin{array}{l}\text { Robertson \& } \\
\text { Shelton, } 1978\end{array}$ & Gulf of Mexico & \\
\hline Pseudohaustorius & americanus & Pearse 1908 & Gulf of Mexico & $33 \%$ \\
\hline
\end{tabular}

*Only includes percent of described species.

$\dagger$ Species complex of at least 5 separate species. The genus is currently under revision by Hoover et al. (in prep).

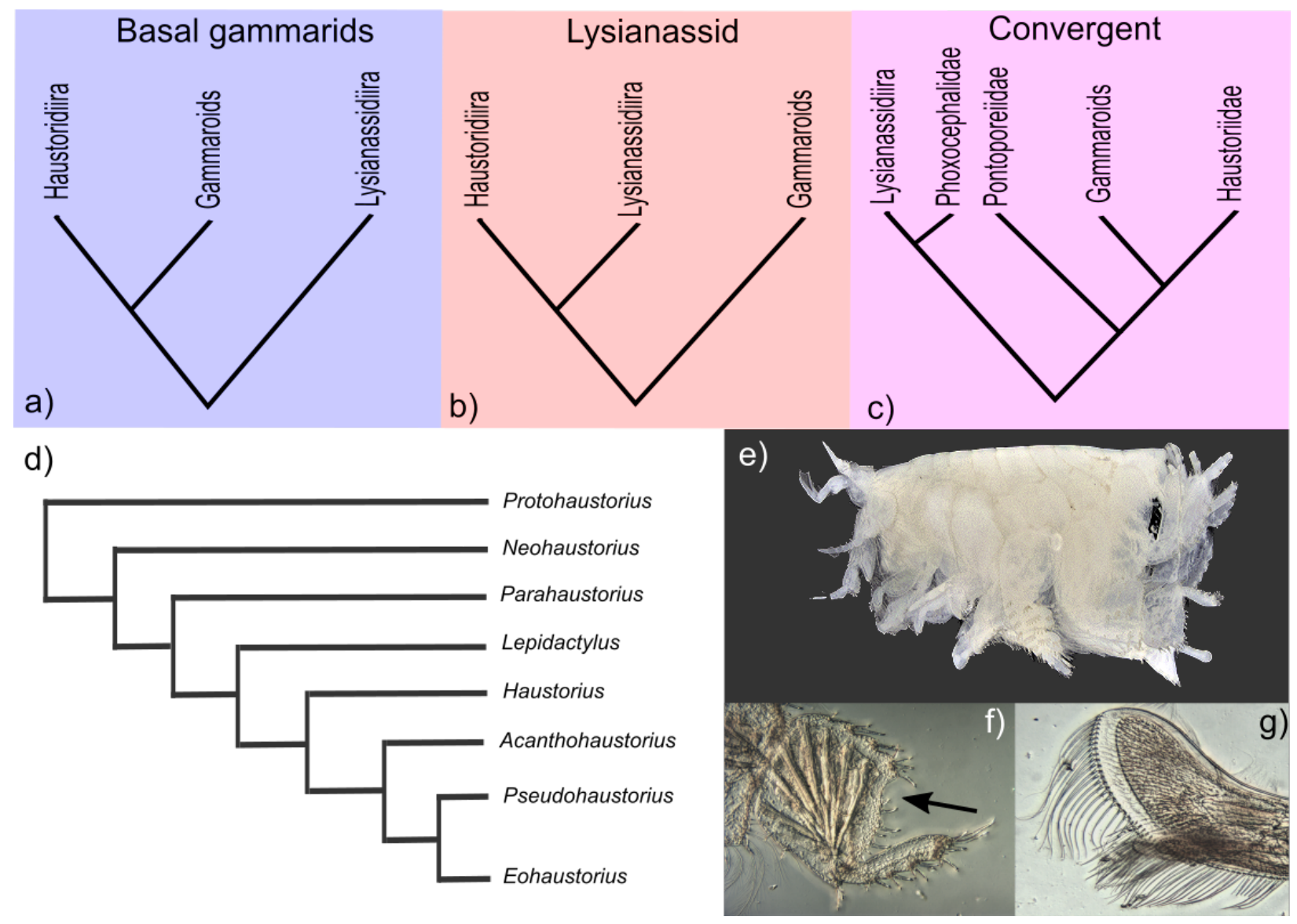


bioRxiv preprint doi: https://doi.org/10.1101/2020.10.24.353664; this version posted October 25, 2020. The copyright holder for this preprint (which was not certified by peer review) is the author/funder, who has granted bioRxiv a license to display the preprint in perpetuity. It is made available under aCC-BY-NC 4.0 International license.

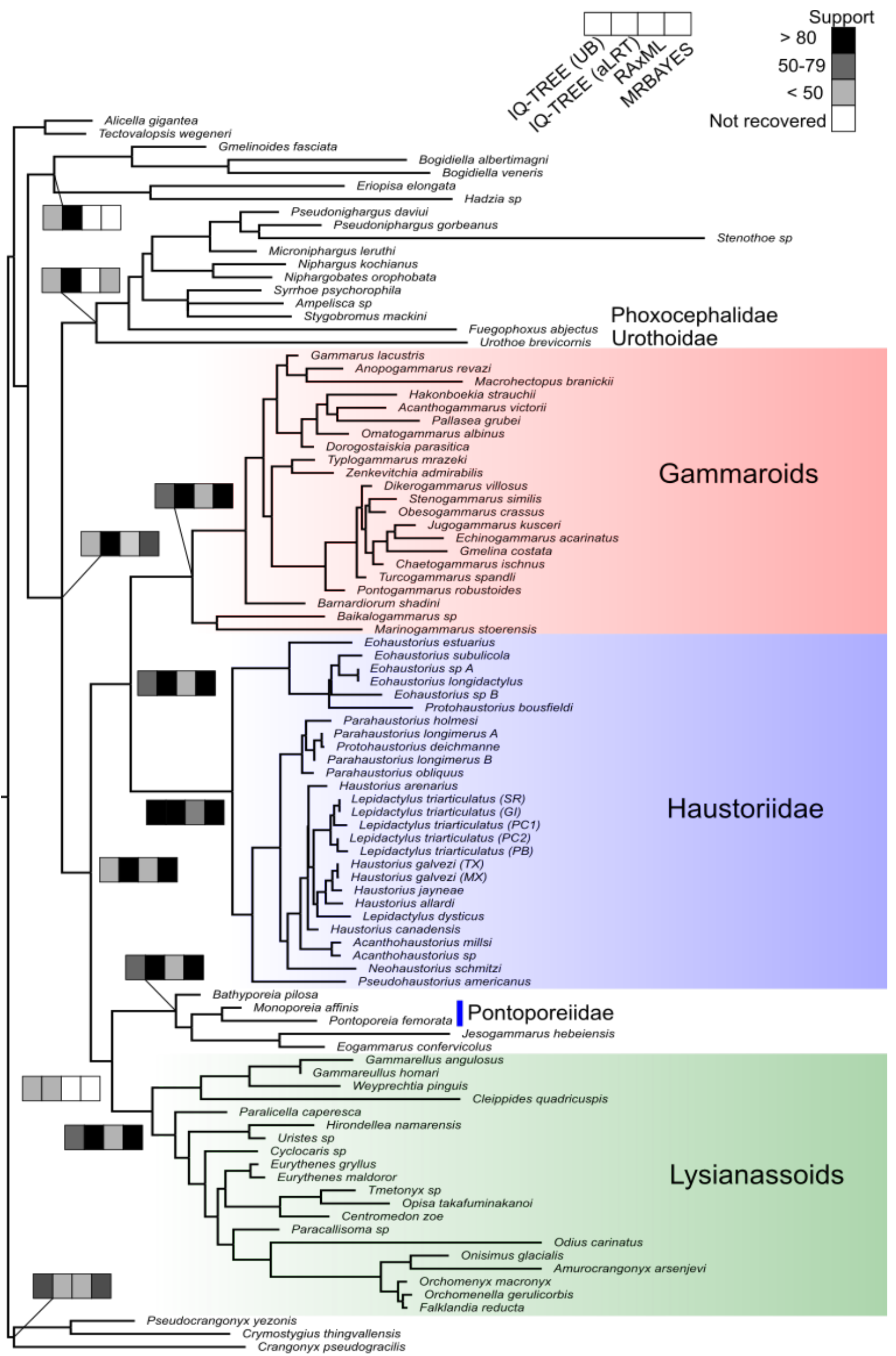


bioRxiv preprint doi: https://doi.org/10.1101/2020 10.24.353664; this version posted October 25, 2020. The copyright holder for this preprint (which was not certified by peer review) is the author/funder, who has granted bioRxiv a license to display the preprint in perpetuity. It is made available under aCC-BY-NC 4.0 International license.
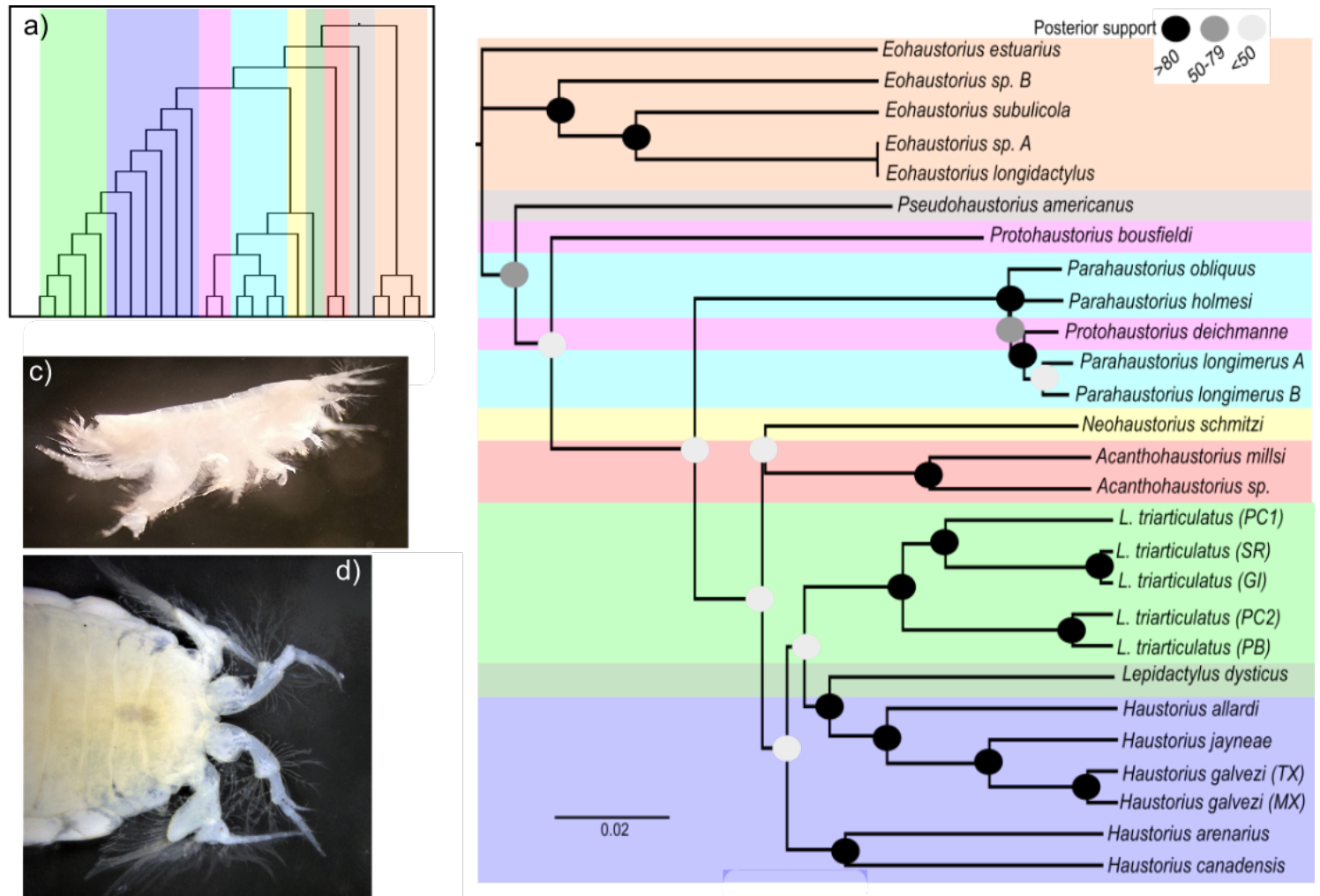

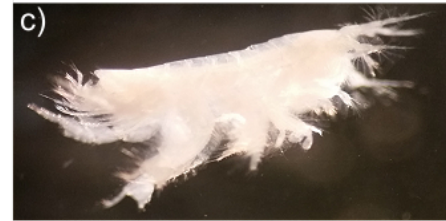

d)

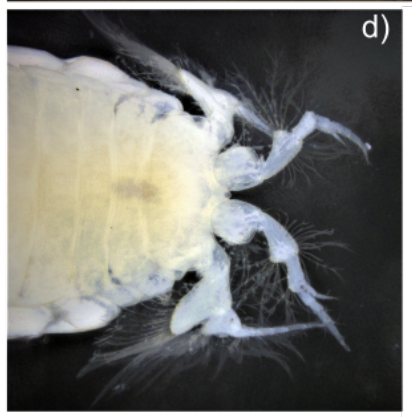

Eohaustorius estuarius

Eohaustorius sp. $B$

Eohaustorius sp. A

Eohaustorius longidactylus

Protohaustorius bousfieldi

Protohaustorius deichmanne

- Parahaustorius longimerus

Acanthohaustorius millsi

L

L. triarticulatus (SR)

L. triarticulatus $(G)$

triarticulatus ( $P C 2$ )

Haustorius allardi

torius jayneae

Haustorius galvezi (MX)

Haustorius canadensis 
bioRxiv preprint doi: https://doi.org/10.1101/2020 1024 353664. this version posted October 25,2020 . The copyright holder for this preprint (which was not certified by peer review) is the author/funder, who has granted bioRxiv a license to display the preprint in perpetuity. It is made available under aCC-BY-NC 4.0 International license.

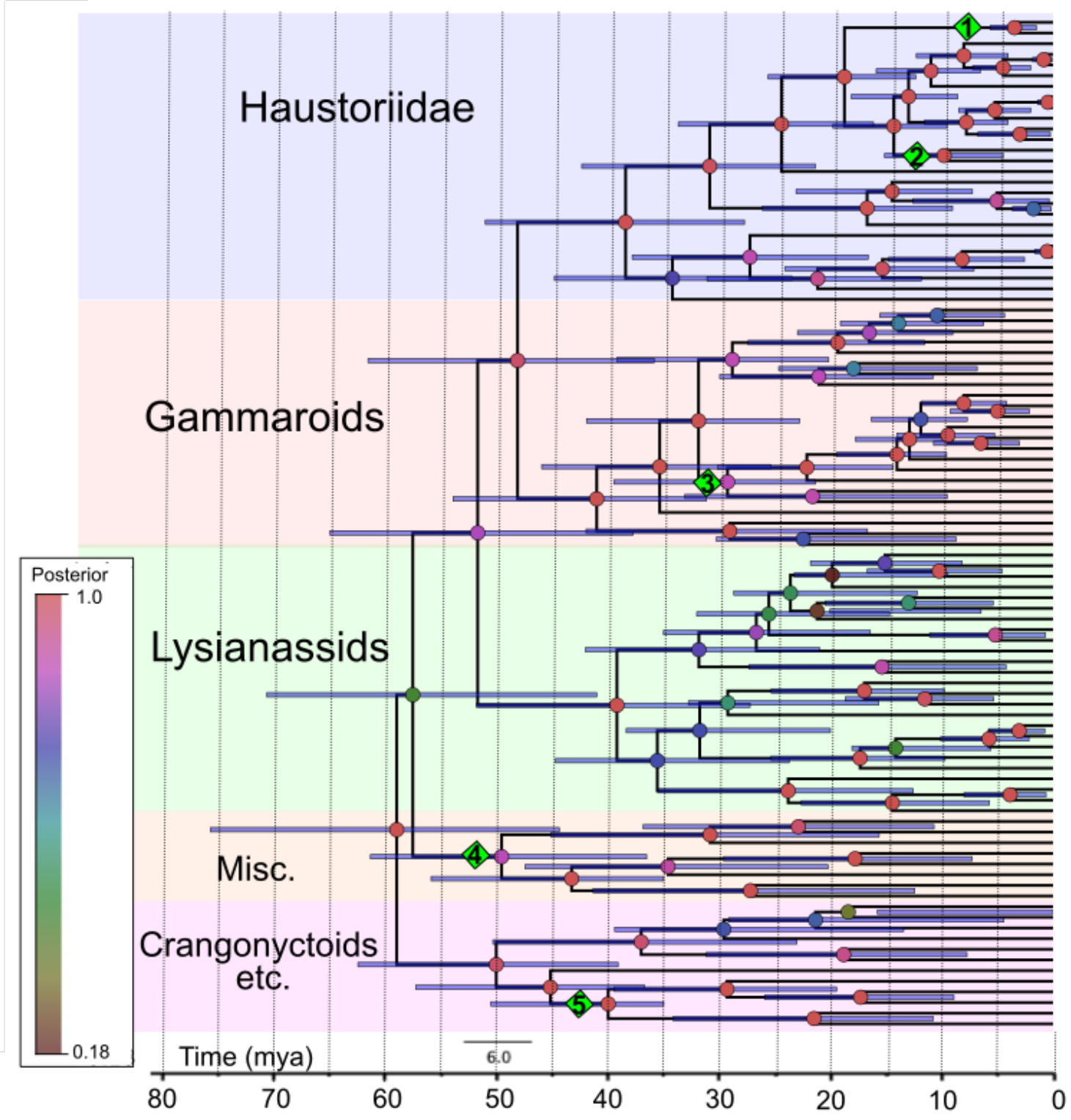


bioRxiv preprint doi: https://doi.org/10.1101/2020.10.24.353664; this version posted October 25, 2020. The copyright holder for this preprint (which was not certified by peer review) is the author/funder, who has granted bioRxiv a license to display the preprint in perpetuity. It is made available under aCC-BY-NC 4.0 International license.

a)

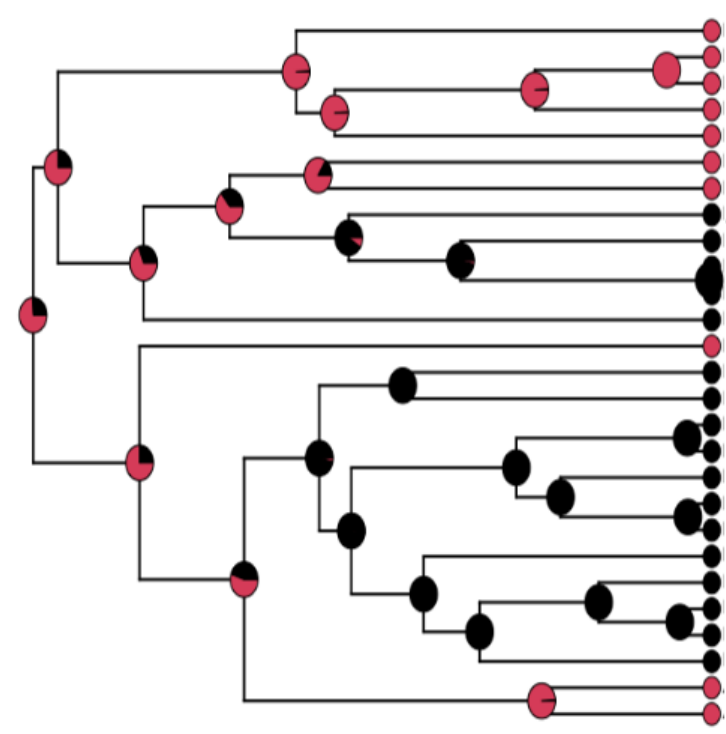

water depth

subtidal

intertidal coastal habitat

b)

Pa. obliquus

Pr. deichmanne Pa. longimerus $A$ $P a$. longimerus $B$ $P$ a. holmesi Ps. americanus Eohaustorius $s p$

E. subulicola

E. longidactylus Ehaustorius sp A E. estuarius

N. schmitzi $H$. arenarius H. canadensis

L. tri. PC2

L. tri. $P B$

L. tri. $P C 1$

L. tri. $S R$

L. tri. GI

L. dysticus

H. jayneae

H. galvezi $T X$
H. galvezi $M X$

H. allardi

A. millsi

A. $s p A$

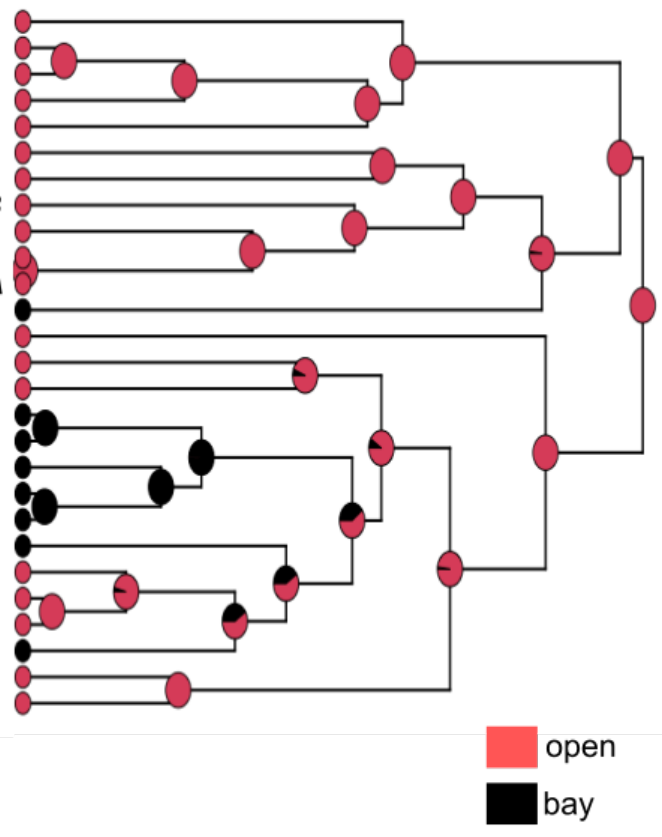




\section{SUPPLEMENTARY MATERIAL}

Alignments and XML files are available at https://github.com/hancockzb.

Figure S1. Saturation plot for $C O I$.

835 Figure S2. IQ-TREE phylogeny for the samples that passeMd the $\chi^{2}$ test. Node values represent aLRT scores.

837 Figure S3. IQ-TREE phylogeny for the samples that passed the $\chi^{2}$ test. Bootstrap values shown 838 at nodes.

839 Figure S4. MrBayes phylogeny for the samples that passed the $\chi^{2}$ test. Posterior probabilities are 840 shown at nodes.

841 Figure S5. Calibration phylogeny from BEAST2 for the samples that passed the $\chi^{2}$ test.

842 Figure S6. Ancestral reconstructions for morphological traits using phytools. Illustrations from

843 LeCroy (2002) and Hancock \& Wicksten (2018). A) Pleon overhangs urosome or not; B) maxilla

8442 outer lobe size relative to inner lobe.

845 Figure S7. Ancestral reconstructions for morphological traits using phytools. Illustrations from 846 LeCroy (2002) and Hancock \& Wicksten (2018). A) Pereopod 6 article 5 distal lobe present or 847 absent; B) pereopod 7 article 4 number of posterior spines.

848 Figure S8. Ancestral reconstructions for morphological traits using phytools. Illustrations from 849 LeCroy (2002) and Hancock \& Wicksten (2018). A) Telsone cleft; B) epimeron 3 with or 850 without hook. 
bioRxiv preprint doi: https://doi.org/10.1101/2020.10.24.353664; this version posted October 25, 2020. The copyright holder for this preprint (which was not certified by peer review) is the author/funder, who has granted bioRxiv a license to display the preprint in perpetuity. It is made available under aCC-BY-NC 4.0 International license.

851 Figure S9. Ancestral reconstructions for bottom preference using phytools.

852

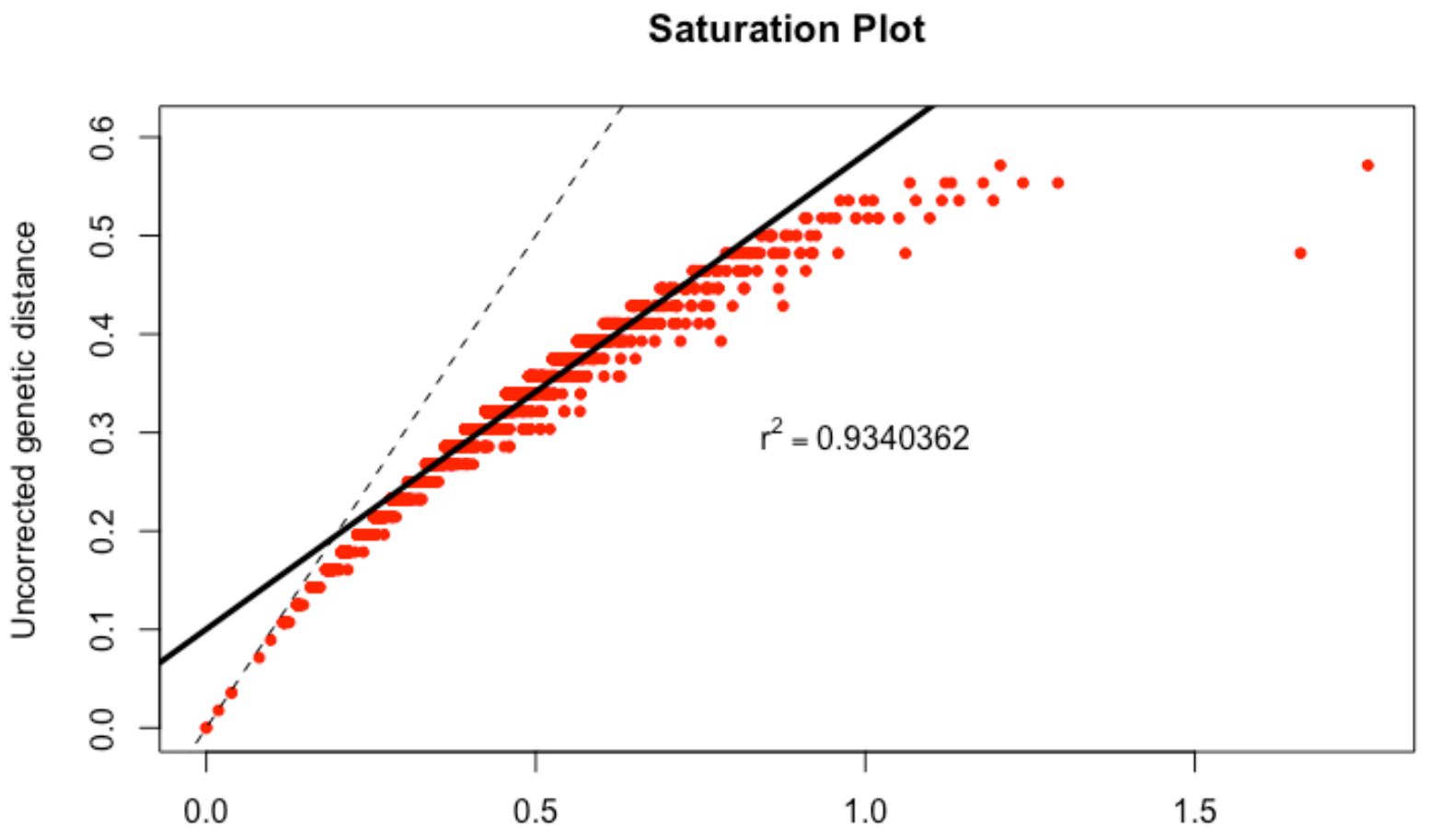

TrN model distance

853

854 
bioRxiv preprint doi: https://doi.org/10.1101/2020.10.24.353664; this version posted October 25, 2020. The copyright holder for this preprint (which was not certified by peer review) is the author/funder, who has granted bioRxiv a license to display the preprint in perpetuity. It is made available under aCC-BY-NC 4.0 International license.

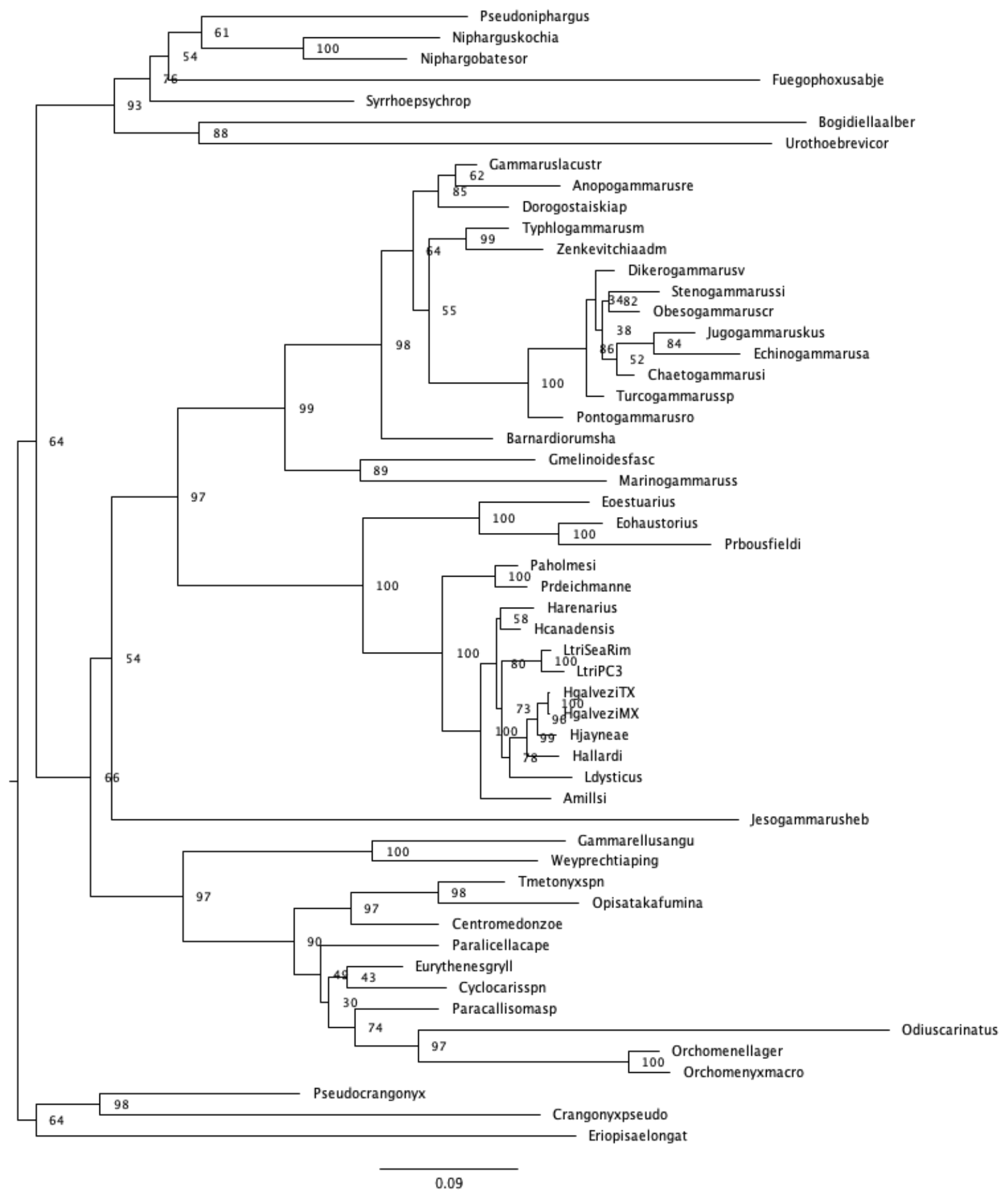


bioRxiv preprint doi: https://doi.org/10.1101/2020.10.24.353664; this version posted October 25, 2020. The copyright holder for this preprint (which was not certified by peer review) is the author/funder, who has granted bioRxiv a license to display the preprint in perpetuity. It is made available under aCC-BY-NC 4.0 International license.

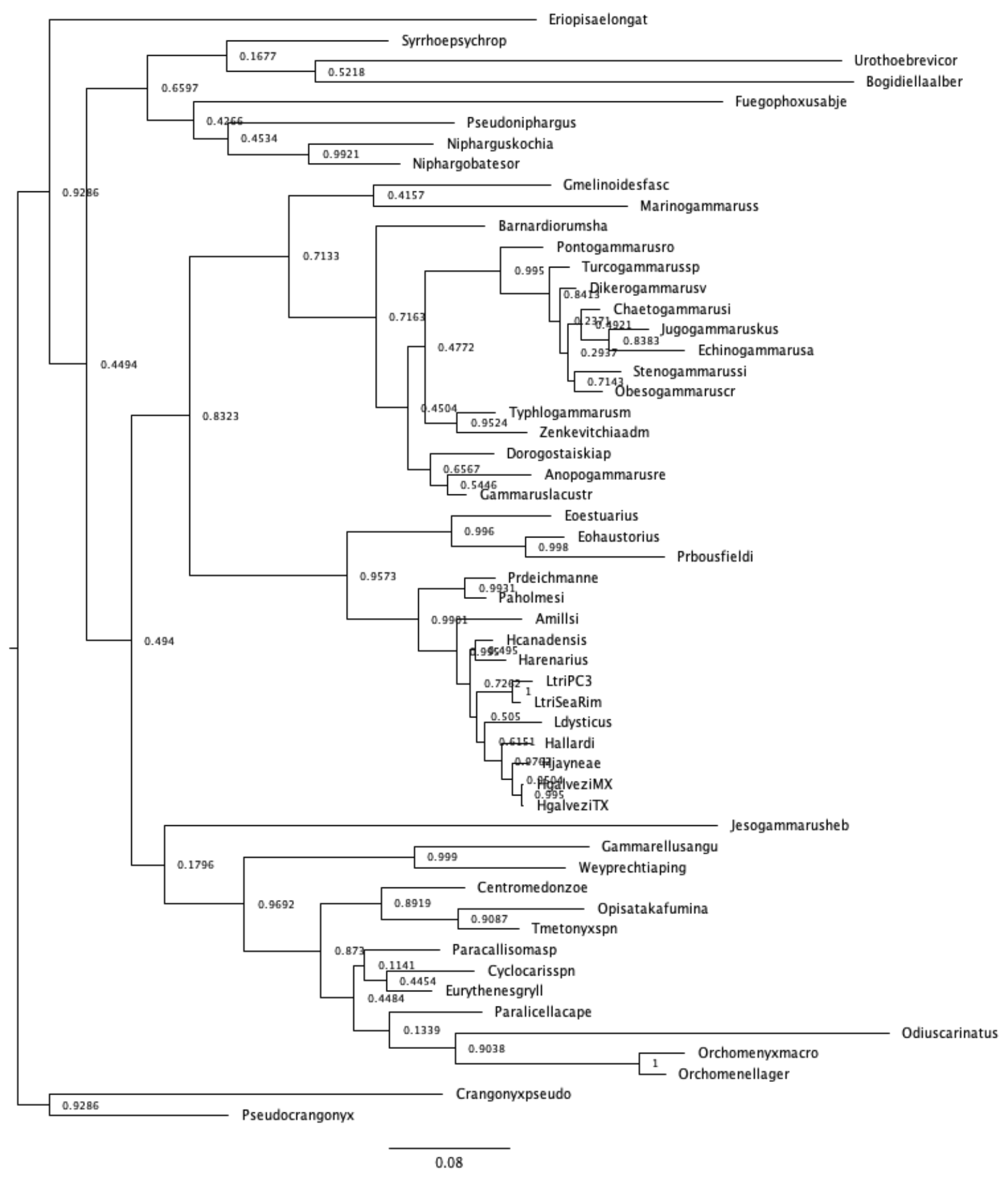


bioRxiv preprint doi: https://doi.org/10.1101/2020.10.24.353664; this version posted October 25, 2020. The copyright holder for this preprint (which was not certified by peer review) is the author/funder, who has granted bioRxiv a license to display the preprint in perpetuity. It is made available under aCC-BY-NC 4.0 International license.

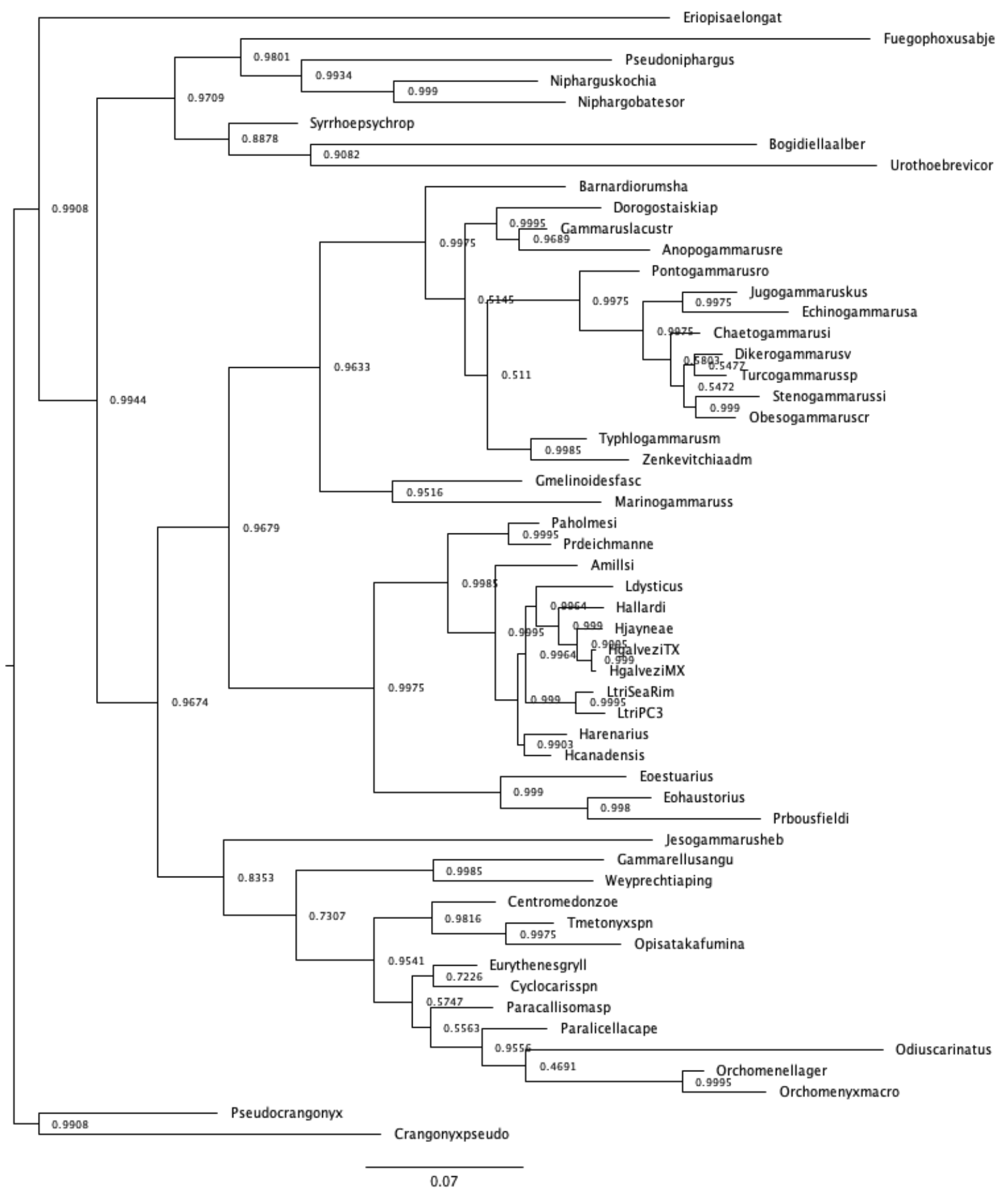


bioRxiv preprint doi: https://doi.org/10.1101/2020.10.24.353664; this version posted October 25, 2020. The copyright holder for this preprint (which was not certified by peer review) is the author/funder, who has granted bioRxiv a license to display the preprint in perpetuity. It is made available under aCC-BY-NC 4.0 International license.
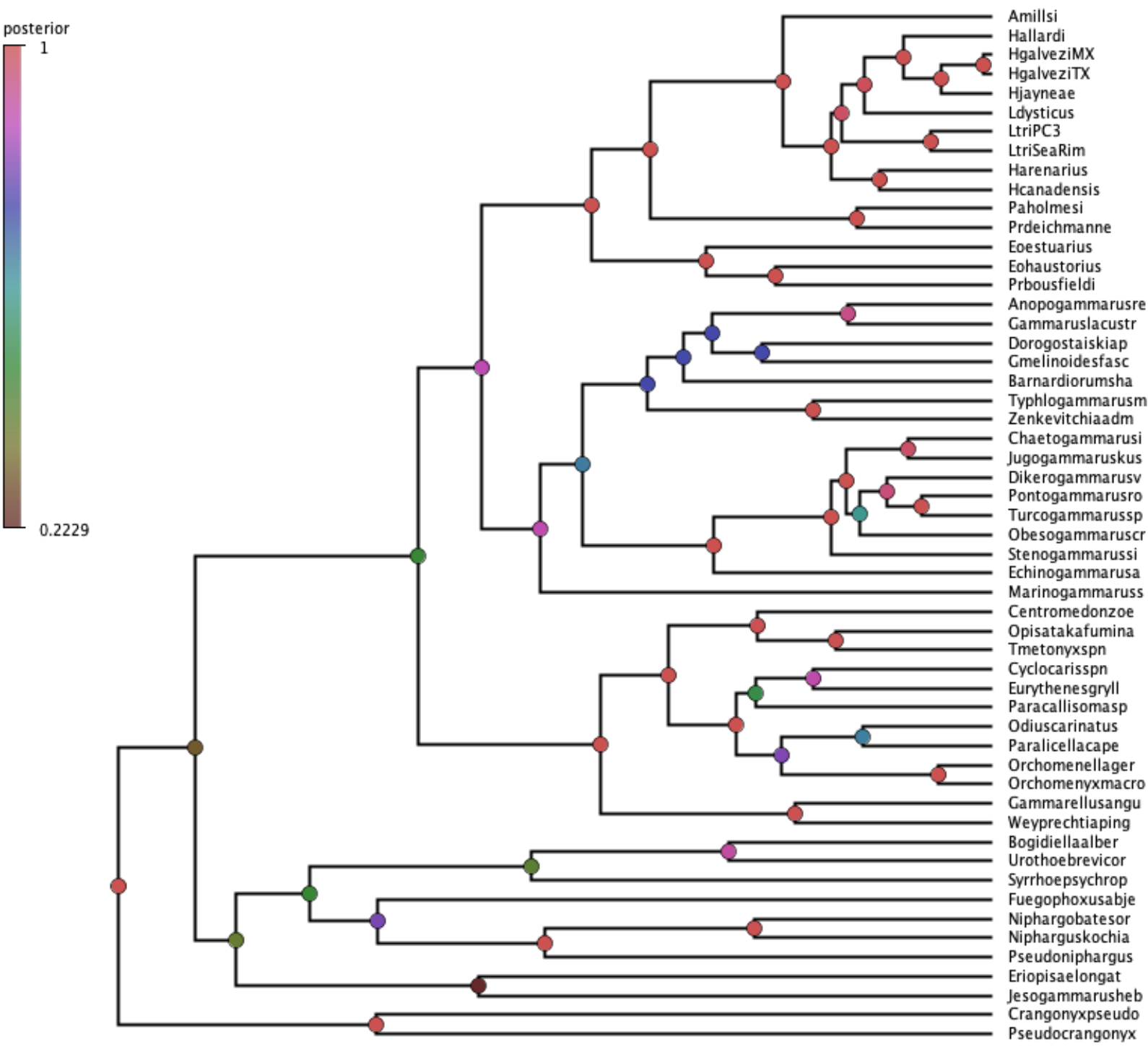
bioRxiv preprint doi: https://doi.org/10.1101/2020.10.24.353664; this version posted October 25, 2020. The copyright holder for this preprint (which was not certified by peer review) is the author/funder, who has granted bioRxiv a license to display the preprint in perpetuity. It is made available under aCC-BY-NC 4.0 International license.

a)

pleon overhangs urosome

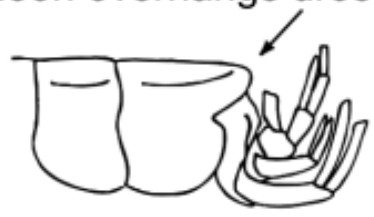

pleon continuous with urosome

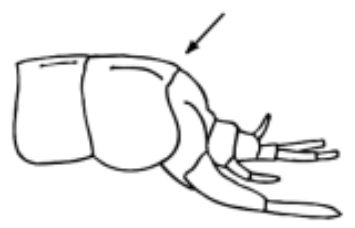

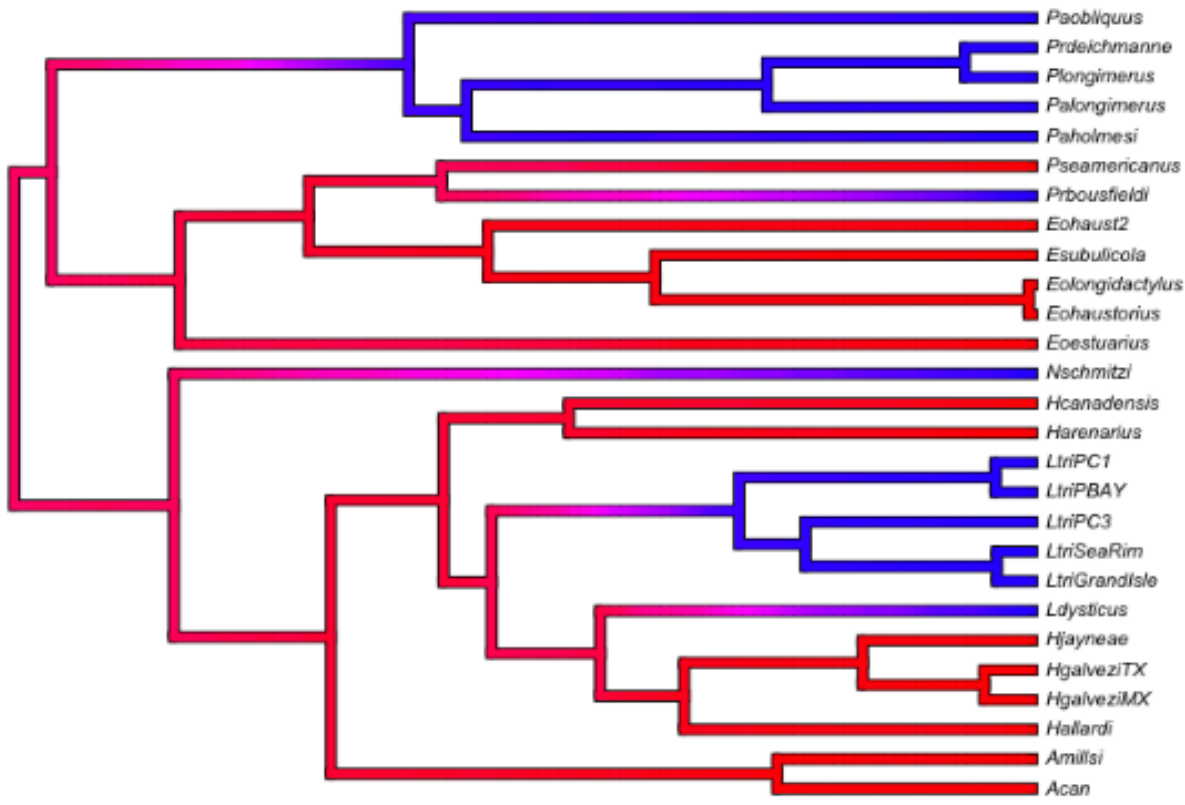

b)

outer lobe $=$ inner lobe

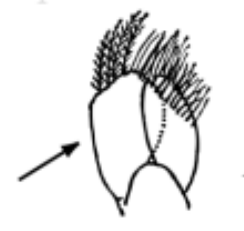

outer lobe > inner lobe

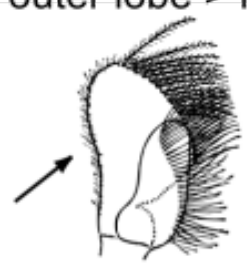

outer lobe >> inner lobe

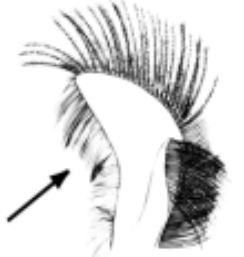

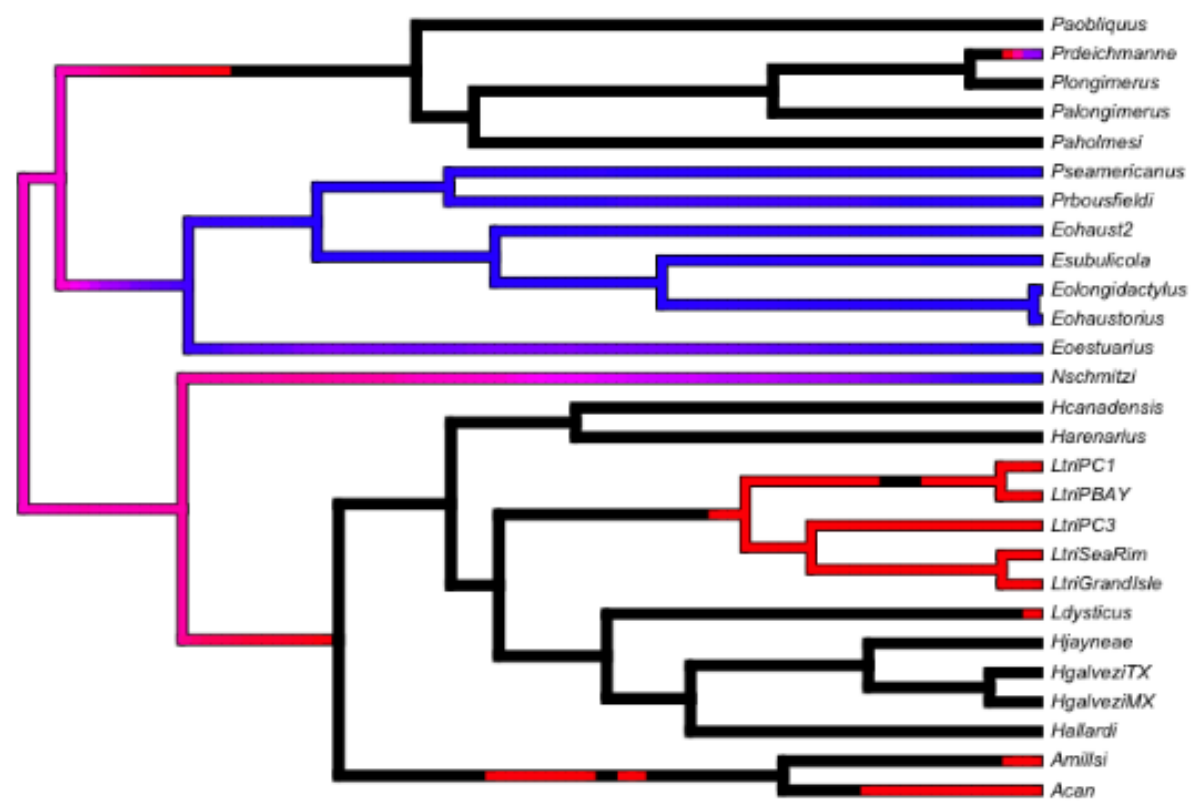


bioRxiv preprint doi: https://doi.org/10.1101/2020.10.24.353664; this version posted October 25, 2020. The copyright holder for this preprint (which was not certified by peer review) is the author/funder, who has granted bioRxiv a license to display the preprint in perpetuity. It is made available under aCC-BY-NC 4.0 International license.

a)

distal lobe absent

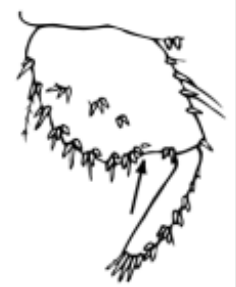

distal lobe present

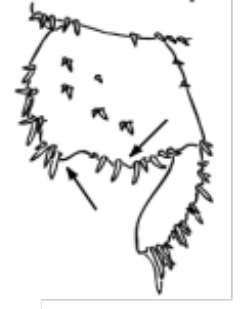

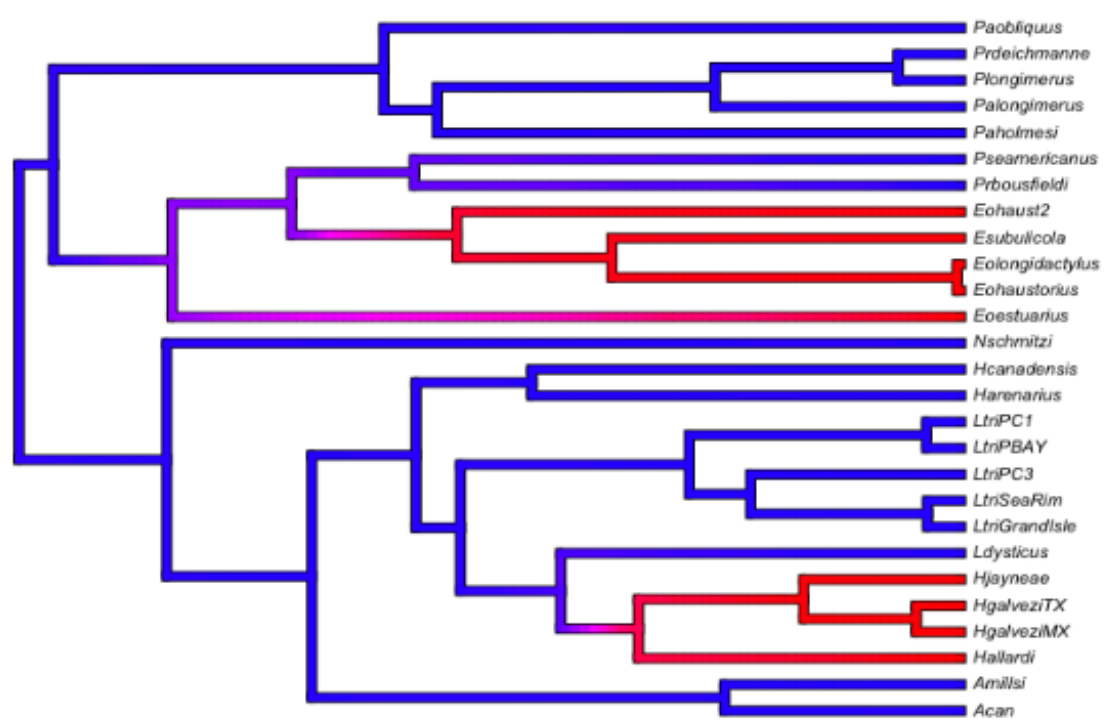

b)
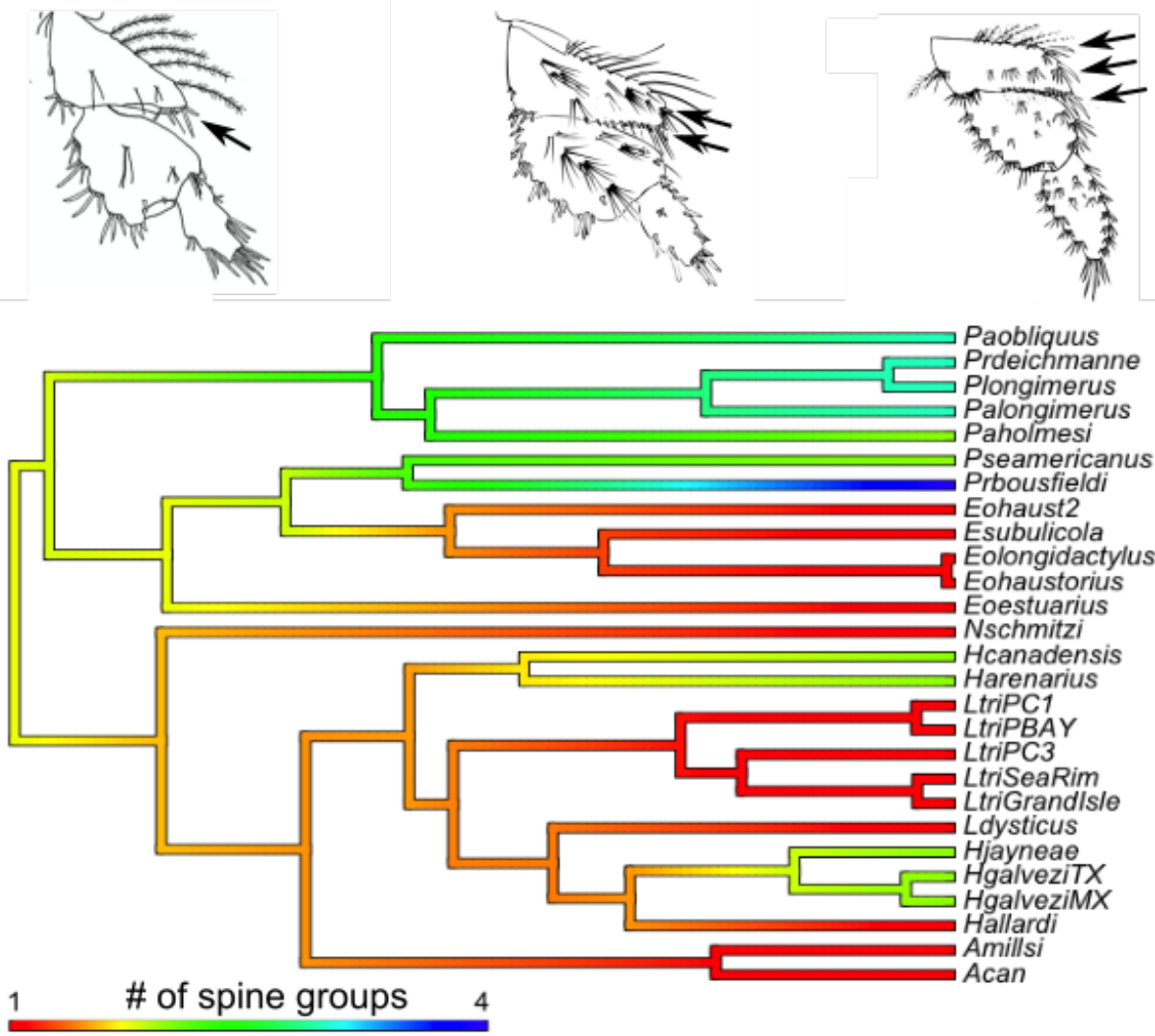
bioRxiv preprint doi: https://doi.org/10.1101/2020.10.24.353664; this version posted October 25, 2020. The copyright holder for this preprint (which was not certified by peer review) is the author/funder, who has granted bioRxiv a license to display the preprint in perpetuity. It is made available under aCC-BY-NC 4.0 International license.
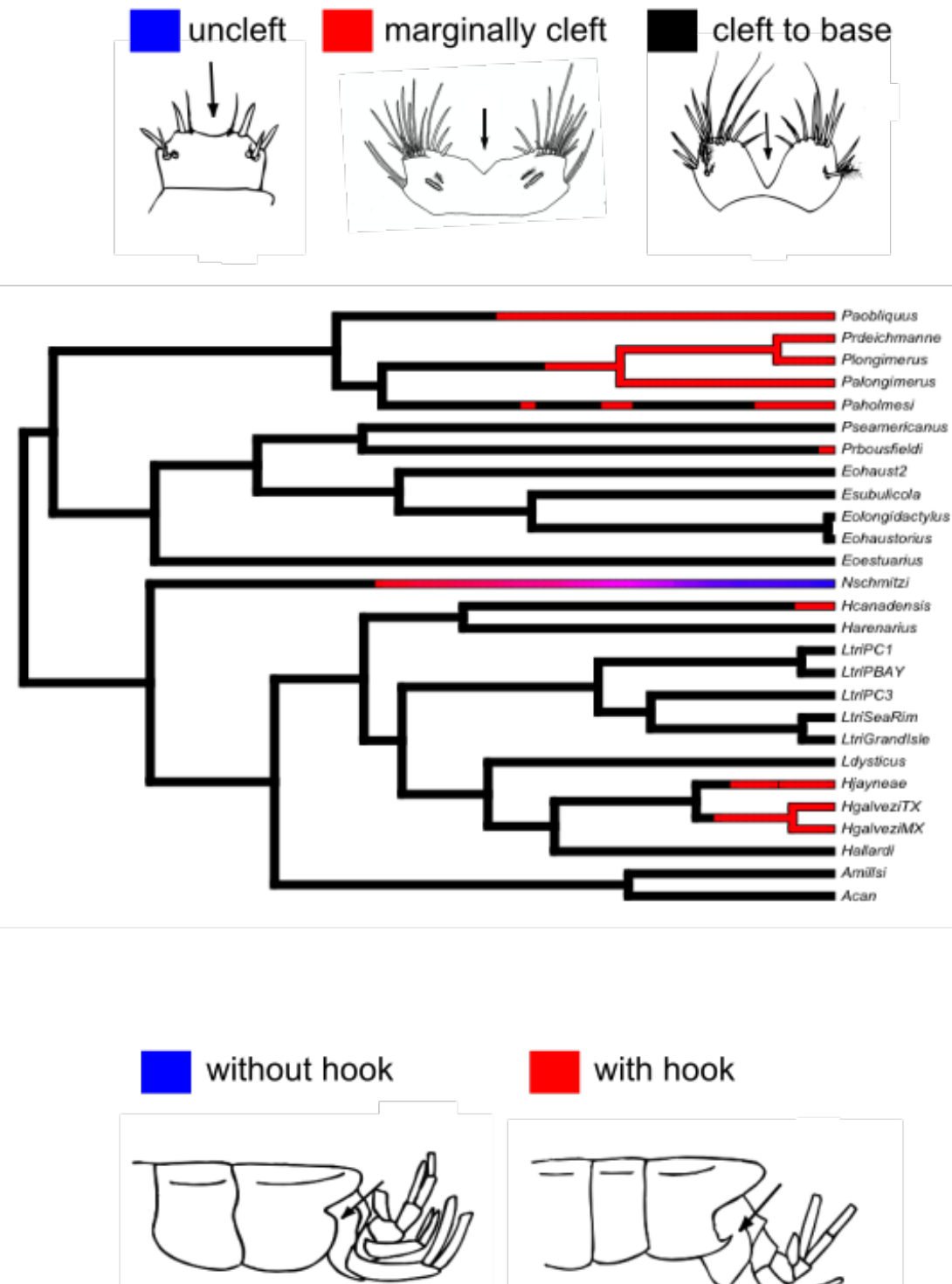

with hook

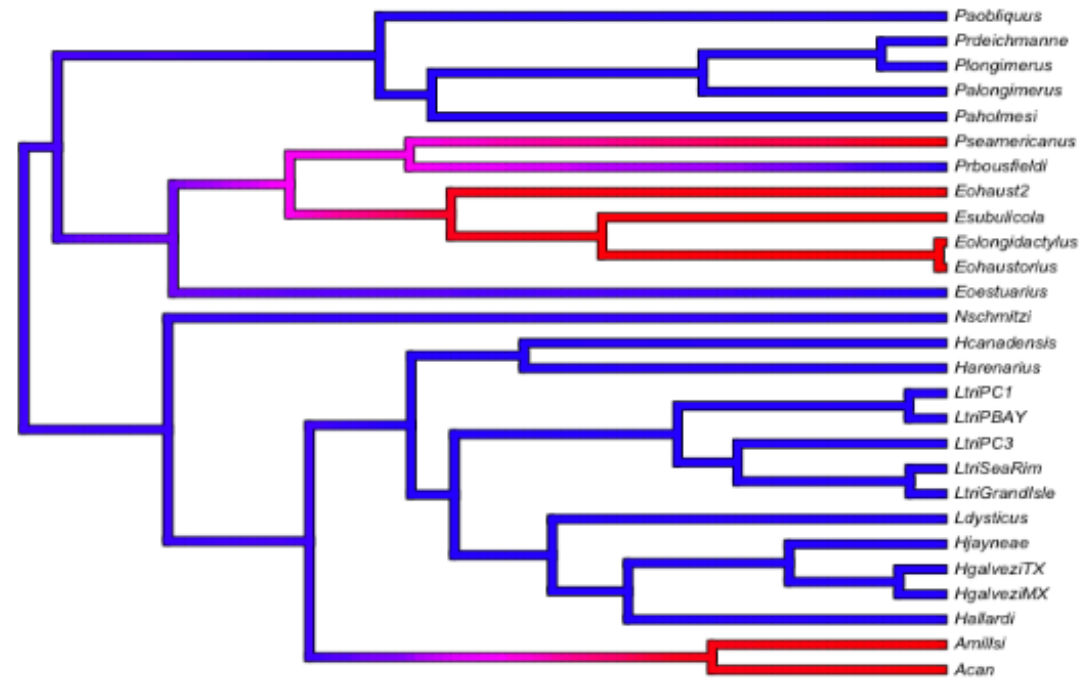


bioRxiv preprint doi: https://doi.org/10.1101/2020.10.24.353664 this version posted October 25, 2020. The copyright holder for this preprint (which was not certified by peer review) is the author/funder, who has granted bioRxiv a license to display the preprint in perpetuity. It is made available under aCC-BY-NC 4.0 International license.

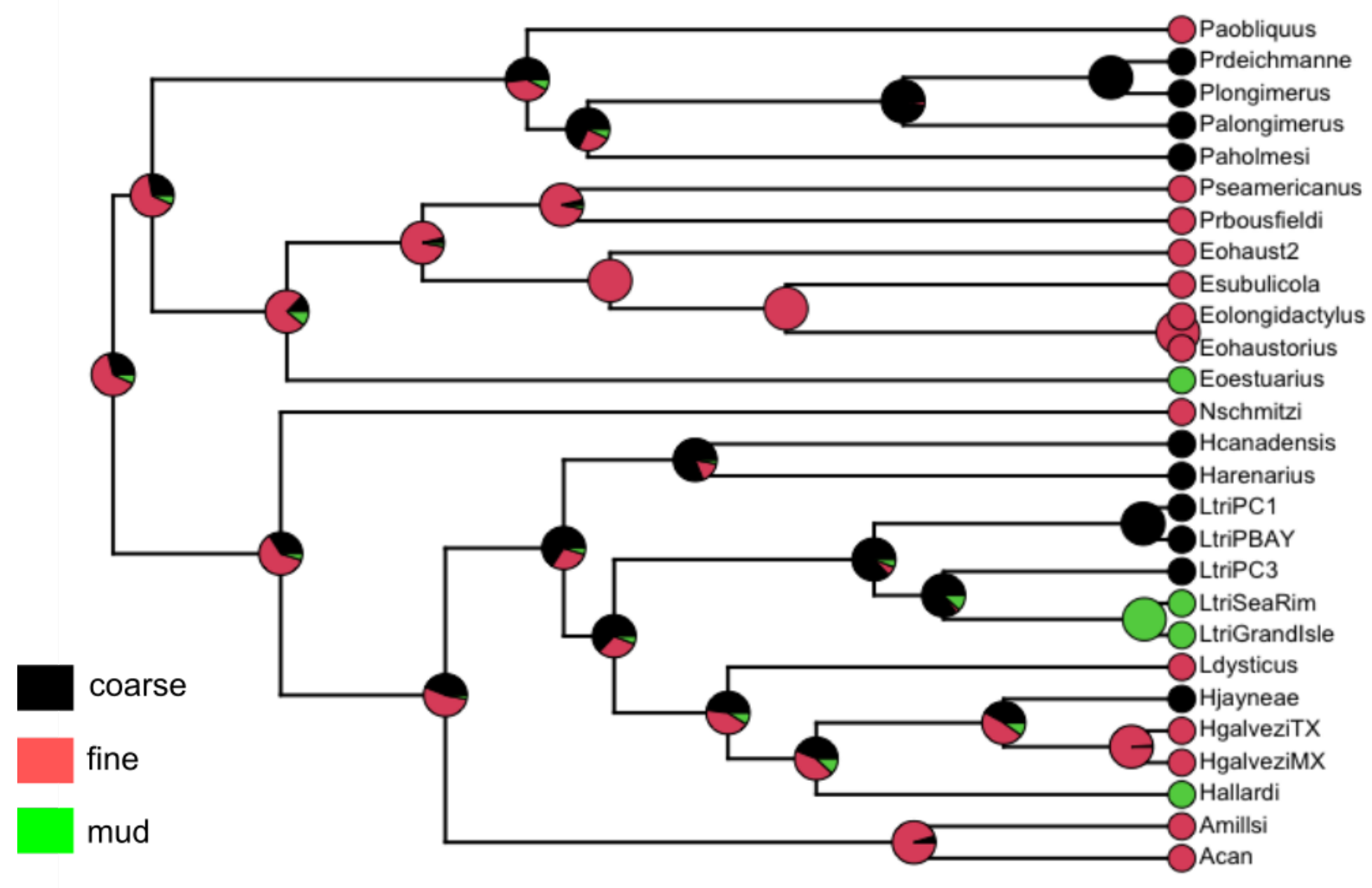

863

864 